\title{
FY2007 NREL Energy Storage R\&D Progress Report
}

Annual Report NREL/TP-540-42716

November 2007

Prepared for input to the DOE Energy Storage R\&D FY2007 Annual Progress Report

Ahmad Pesaran (Principal Investigator)

\section{Contributors:}

Matt Keyser, Gi-Heon Kim, Kandler Smith, Jason Lustbader, Tony Markel, Jeff Gonder, Anne Dillon, Se-Hee Lee, Yong-Hyun Kim, Dane Gillaspie, Erin Whitney, Art Frank, Kai Zhu, and Qing Wang 


\section{FY2007 NREL Energy Storage R\&D Progress Report}

Ahmad Pesaran (Principal Investigator)

\section{Contributors:}

Matt Keyser, Gi-Heon Kim, Kandler Smith, Jason Lustbader, Tony Markel, Jeff Gonder, Anne Dillon, Se-Hee Lee, Yong-Hyun Kim, Dane Gillaspie, Erin Whitney, Art Frank, Kai Zhu, and Qing Wang

Prepared under Task Nos. FC07.6000 and FC07.6200

National Renewable Energy Laboratory

1617 Cole Boulevard, Golden, Colorado 80401-3393

303-275-3000 • www.nrel.gov

Operated for the U.S. Department of Energy

Office of Energy Efficiency and Renewable Energy

by Midwest Research Institute • Battelle

Contract No. DE-AC36-99-G010337

\section{Annual Report} NREL/TP-540-42716

November 2007

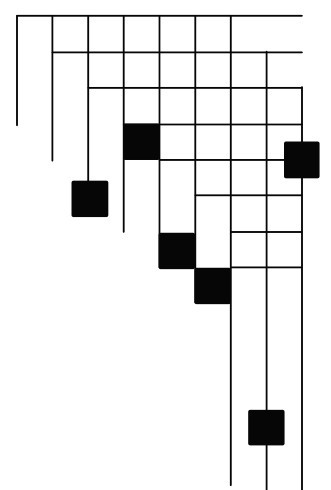




\section{NOTICE}

This report was prepared as an account of work sponsored by an agency of the United States government. Neither the United States government nor any agency thereof, nor any of their employees, makes any warranty, express or implied, or assumes any legal liability or responsibility for the accuracy, completeness, or usefulness of any information, apparatus, product, or process disclosed, or represents that its use would not infringe privately owned rights. Reference herein to any specific commercial product, process, or service by trade name, trademark, manufacturer, or otherwise does not necessarily constitute or imply its endorsement, recommendation, or favoring by the United States government or any agency thereof. The views and opinions of authors expressed herein do not necessarily state or reflect those of the United States government or any agency thereof.

Available electronically at http://www.osti.gov/bridge

Available for a processing fee to U.S. Department of Energy and its contractors, in paper, from:

U.S. Department of Energy

Office of Scientific and Technical Information

P.O. Box 62

Oak Ridge, TN 37831-0062

phone: 865.576 .8401

fax: 865.576 .5728

email: mailto:reports@adonis.osti.gov

Available for sale to the public, in paper, from:

U.S. Department of Commerce

National Technical Information Service

5285 Port Royal Road

Springfield, VA 22161

phone: 800.553.6847

fax: 703.605.6900

email: orders@ntis.fedworld.gov

online ordering: http://www.ntis.gov/ordering.htm 


\title{
FY2007 NREL Energy Storage Program Report National Renewable Energy Laboratory
}

November 2007

\author{
Ahmad Pesaran (Principal Investigator) \\ National Renewable Energy Laboratory \\ 1617 Cole Boulevard \\ Golden, CO 80401-3393 \\ (303) 275-4441 \\ ahmad_pesaran@nrel.gov
}

\section{Contributors:}

Matt Keyser, Gi-Heon Kim, Kandler Smith, Jason Lustbader, Tony Markel, Jeff Gonder, Anne Dillon, Se-Hee Lee, Yong-Hyun Kim, Dane Gillaspie, Erin Whitney,

Art Frank, Kai Zhu, and Qing Wang

Prepared for

\section{FY07 DOE Energy Storage R\&D Annual Progress Report \\ David Howell (Technology Manager) \\ Tien Duong (Team Lead) \\ Ed Wall (Office Director) \\ Office of Vehicle Technologies \\ US Department of Energy \\ Washington, DC}

\begin{abstract}
The National Renewable Energy Laboratory is engaged in research and development activities to support achieving targets and objectives set by the Energy Storage Program at the Office of FreedomCAR and Vehicle Technology in the U.S. Department of Energy. These activities include: 1. supporting the Battery Technology Development Program with battery thermal characterization and modeling and with energy storage system simulations and analysis; 2. supporting the Applied Research Program by developing thermal models to address abuse of Li-Ion batteries; and 3. supporting the Focused LongTerm Research Program by investigating improved Li-Ion battery electrode materials. This report summarizes the results of NREL energy storage activities in FY07.
\end{abstract}

\section{Summary}

During FY 2007, we:

- Supported FreedomCAR battery developers by measuring thermal characteristics and properties of cells and modules

- Evaluated two generations of lithium-ion cells from Johnson Controls-Saft 
- Characterized lithium polymer batteries from Compact Power Inc.

- Thermally evaluated a 42-volt, liquid-cooled, battery module from Saft

- Designed and nearly completed construction of a large calorimeter for testing PHEV modules and sub-packs

- Evaluated use of phase-change materials from AllCell for thermal management of batteries in hybrid vehicles.

- Evaluated differences between air and liquid cooling for battery packs as part of a general effort to develop analysis and design systems for battery thermal management

- Initiated development of a three-dimensional model for lithium-ion battery performance in support of thermal abuse modeling

- Evaluated the impact of changes in battery energy windows on fuel economy of power-assist hybrid electric vehicles

- Developed an approach for tradeoff analysis between performance, cost, and life of batteries for use in plug-in hybrid-electric vehicles

- Supported the U. S. Advanced Battery Consortium with analyses and participation at various workgroups including supporting developing PHEV battery requirements and targets

- Designed and evaluated a battery management system and a lithium-ion polymer battery pack for use in a neighborhood electric vehicle.

- Supported the efforts of the International Energy Agency hybrid electric vehicle program with analyses and annex participation

- Developed and improved models for thermal runaway of lithium-ion battery cells and propagation in modules

- Investigated the use of novel nanostructured molybdenum oxide nanoparticles for improving characteristics of electrodes for lithium-ion batteries

- Studied the use of ordered nanotube titanium oxide materials to improve electrode characteristics in lithium-ion batteries.

\section{Battery Technology Development}

In support of the Battery Technology Development element of the U.S. Department of Energy (DOE) Program, the National Renewable Energy Laboratory (NREL) performs research in a. battery thermal analysis and characterization and b. energy storage system simulation and requirements analysis. NREL also provides support to industry and to international energy storage programs.

- Proper thermal control is critical to achieve life, performance, cost, and safety goals of the energy storage system for vehicle applications under the FreedomCAR and Vehicle Technologies (FCVT) program. Poor thermal control could lead to a reduction in battery performance and thus substantial increase in cost, reduced cycle and calendar life, and increased chance of abuse conditions. This activity addresses issues related to battery thermal control and improving the thermal performance of energy storage devices through thermal characterization 
and testing, measuring thermal properties, modeling, analysis, and control strategies.

- Simulation and requirements analysis aim at developing models and tools for simulating behavior of energy storage devices and then using them in existing vehicle simulation tools. The models and tools are then used to support DOE and

the FreedomCAR Energy Storage Technical Team to identify the requirements and attributes of energy storage systems (batteries and ultracapacitors or combinations) to make advanced vehicles such as micro and mild hybrids, powerassist hybrids, and plug-in hybrid vehicles more efficient and affordable.

- NREL also provides general analysis support to industrial and international energy storage programs such as the U.S. Advanced Battery Consortium and the International Energy Agency and to individual companies when in-line with DOE program objectives.

\subsection{Battery Thermal Analysis and Characterization Activities}

Battery developers (Johnson Controls-Saft, CPI/LG Chem, and Saft) provided permission to publish the following high-level summaries. Further details are considered "Protected Information" and could not be shared.

Measured Johnson Control - Saft Cell Thermal Properties to Provide Insight to the Freedom CAR Battery Developer - To generate data for the design of a battery thermal management system, this effort measured the thermal characteristics of two generations of Johnson Controls - Saft's (JCS) lithium-ion cells. The two generations of 6-Ah (ampere-hour) capacity cells were similar except for the carbon used in the anode. Both were tested in NREL's advanced calorimeter to determine cell heat-generation rates and efficiency under various loads. The Gen 1 cell was tested with the calorimeter at $0^{\circ} \mathrm{C}$ and $30^{\circ} \mathrm{C}$. The Gen 2 cell was tested with the calorimeter at $-30^{\circ} \mathrm{C},-15^{\circ} \mathrm{C},-5^{\circ} \mathrm{C}, 0^{\circ} \mathrm{C}, 5^{\circ} \mathrm{C}$, and $30^{\circ} \mathrm{C}$. There were negligible differences in heat generation and efficiency between the two generations of cells at $0^{\circ} \mathrm{C}$ and $30^{\circ} \mathrm{C}$. For the Gen 2 cell, the heat generation under a 30 amps discharge was 2 Watts at $30^{\circ} \mathrm{C}$ and 18 watts at $-30^{\circ} \mathrm{C}$. This corresponded to efficiencies of $98 \%$ and $79 \%$, respectively. Heat generation of the Gen 2 cell as a function of temperature and discharge current from full charge to zero charge is presented here. As expected, the heat generation increased as the temperature of the cell decreased. Furthermore, NREL measured the heat capacity of the Gen 2 cell. It should be noted that the 6-amp discharge capacity of the Gen 2 cell at $-30^{\circ} \mathrm{C}$ is approximately $50 \%$ of the discharge capacity at $30^{\circ} \mathrm{C}$, reasonably high at this very cold condition.

NREL also took infrared thermal images of the cells while undergoing an aggressive 72amp discharge from $100 \%$ to $0 \%$ state of charge (SOC). After the 72 -amp discharge, slight preferential heating was noted at the negative terminal compared to the positive terminal for both generations of the cell. We found no areas of thermal concern or hot spots on the cell during the thermal imaging. These results were shared with JCS and will be used for thermal design of battery packs. In FY08, NREL will continue thermal characterization of JCS and other FreedomCAR batteries. 

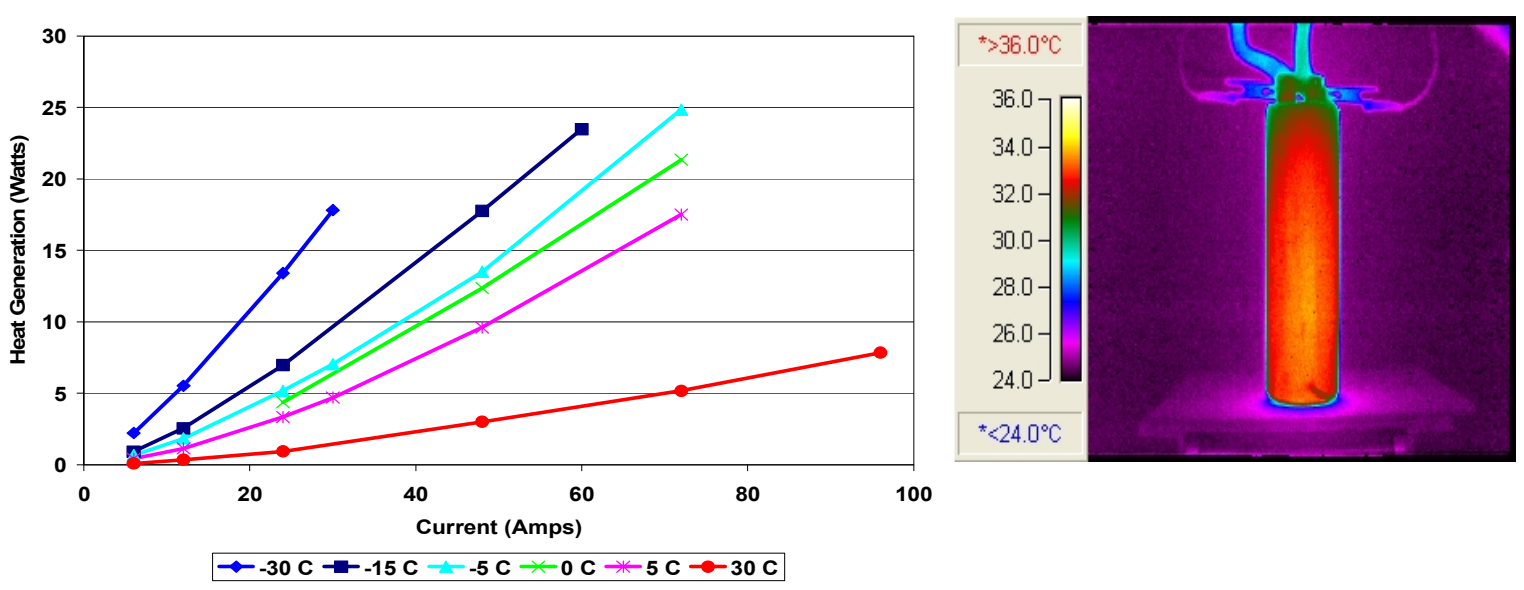

Figure 1. Heat generation rate of JCS Gen 2 Cells at various temperatures and currents from 100\% to 0\% SOC (left). Thermal image of Gen 2 Cell at the end of a 72-amp constant current discharge (right).

Thermally Characterized CPI/LG Chem Cells to Aid Thermal Design of Packs - In support of the Compact Power, Inc. (CPI) and LG Chem battery development program with FreedomCAR/DOE and the U.S. Advanced Battery Consortium (USABC), NREL took thermal characteristics of their prototype Gen 4.2 cells. The lithium polymer cells, with a carbon anode and manganese cathode, are developed for power-assist hybridelectric vehicle (HEV) applications. NREL measured the heat generation rate and efficiency of the cells in our calorimeter at temperatures of $-30^{\circ} \mathrm{C},-15^{\circ} \mathrm{C}, 0^{\circ} \mathrm{C}, 30^{\circ} \mathrm{C}$ and $45^{\circ} \mathrm{C}$. The efficiency of the cell during constant current discharge at $30^{\circ} \mathrm{C}$ was $97.6 \%$ at the $\mathrm{C} / 1$ rate and $86.7 \%$ at the $20 \mathrm{C}$ rate (where $\mathrm{C}$ is rated capacity). Efficiency measured for a scaled power profile derived from the US06 driving cycle of a midsize hybrid car, meant to represent an aggressive use of the battery, was $95.7 \%$. Both the US06 profile and a geometric cycle, consisting of pulse charging and discharging at around $50 \%$ stateof-charge, generated less heat than full constant current discharge tests at comparable currents. Additional tests confirmed that the end-of-discharge portion (near $0 \% \mathrm{SOC}$ ) of the constant current discharge tests produces far more heat than the middle portion (near $50 \%$ SOC), dominating the average heat generation measurement, a condition that will not be experienced when operating batteries in HEVs .

NREL also measured heat capacity of the cells and took infrared thermal images of the CPI Gen 4.2 cells. Thermal imaging during aggressive cycling of the cells showed a maximum spatial temperature difference on the exterior of cell at end of discharge was about $5^{\circ} \mathrm{C}$. The electrochemically active region of the cells' exterior was even more uniform, generally within $2^{\circ} \mathrm{C}$. Slightly elevated temperatures were observed at the positive terminal compared to negative terminal, perhaps because of the low electrical conductivity and smaller heat capacity of the aluminum foil carrying current to and from the positive electrode. There were no hot spots or areas of thermal concern. These results were shared with CPI/LG Chem to enable them to design modules with improved thermal performance for better in-vehicle battery pack thermal management. 

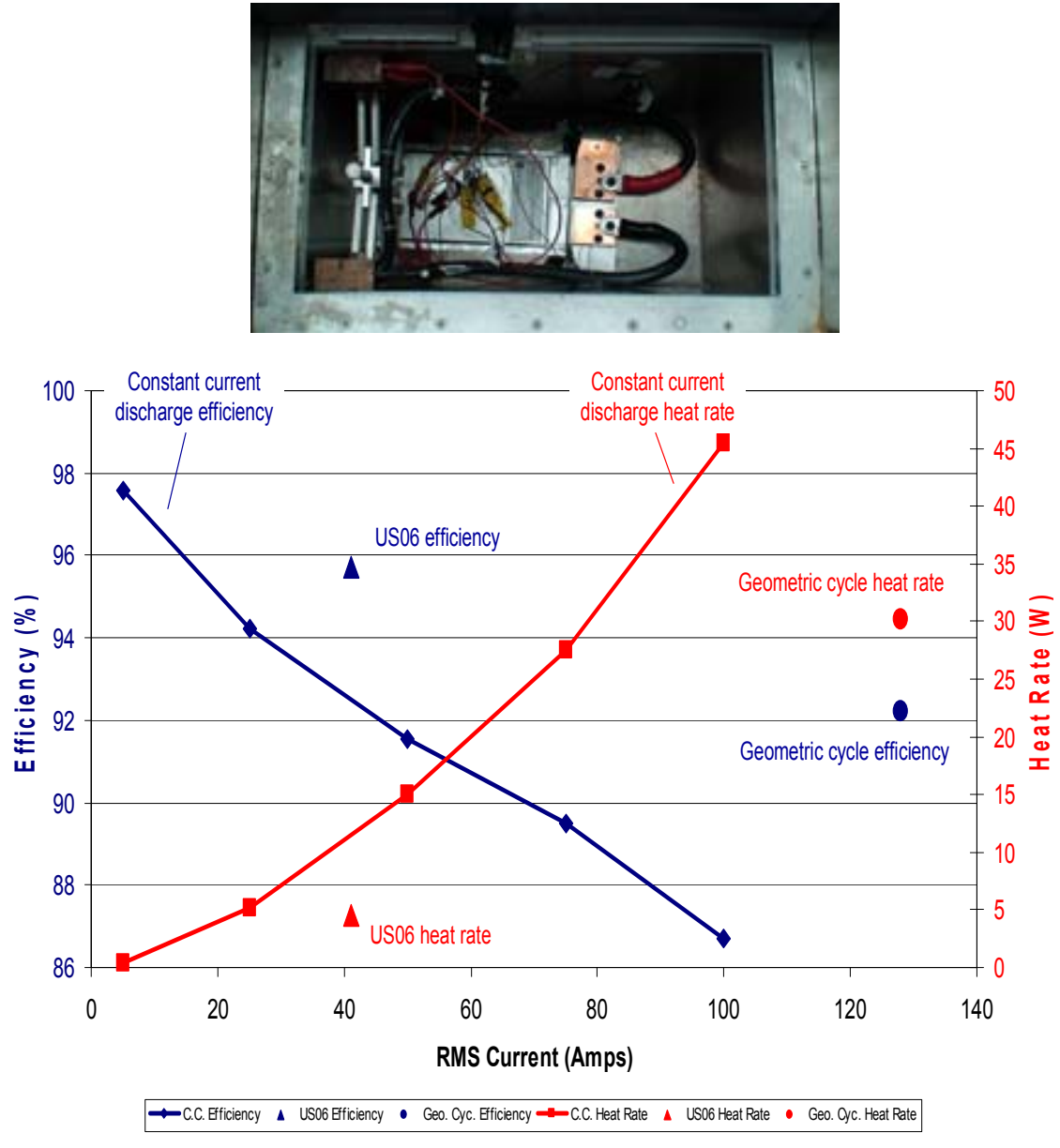

Figure 2. CPI Gen 4.2 cell inside NREL's calorimeter test chamber (top). Heat generation rate and efficiency for various profiles at $30^{\circ} \mathrm{C}$ (bottom).
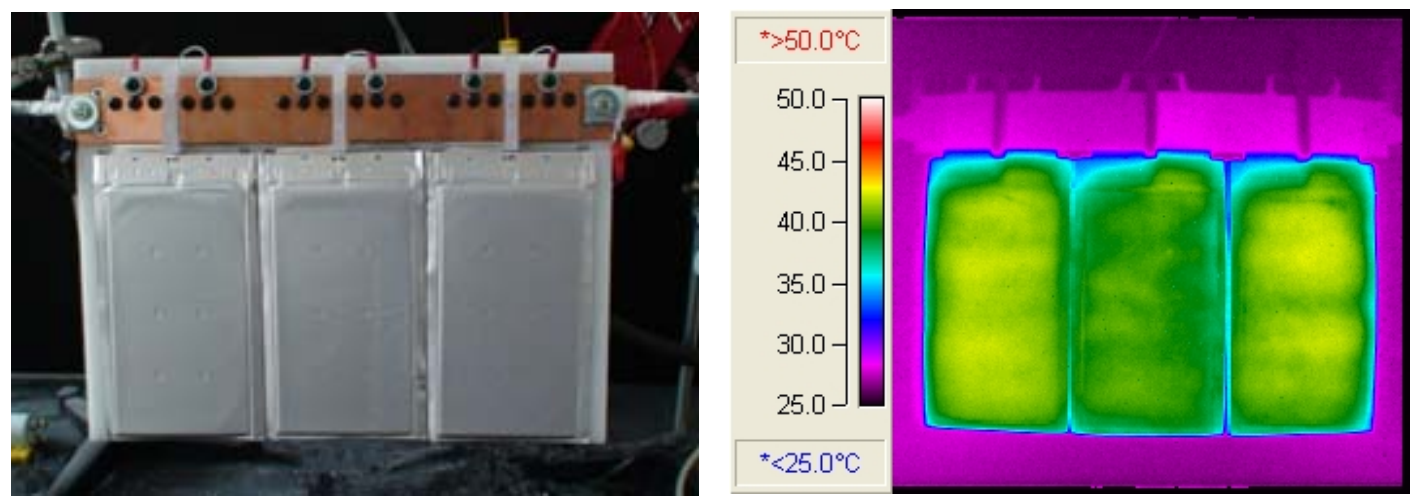

Figure 3. Three CPI cells connected in series (left). Infrared thermal image of the cells at the end of 20C (discharge (right). The thermal performance of the center cell is representative of most of cells in a module. 
Completed Thermal Evaluation of Saft 42-V Liquid-Cooled Module - NREL completed testing of the Saft VL20P liquid-cooled 42-V module, evaluating its thermal performance and developing a data set for thermal model validation and battery model development. The Saft VL20P module was a final deliverable for the Saft program with FreedomCAR/USABC, which ran from FY2003 through FY2006) and consisted of twelve 20-Ah cells. NREL had previously assisted Saft with thermal design trade-offs of different cooling approaches during the design process (FY2003 - FY2005). Saft selected liquid cooling because of anticipated aggressive power profiles for $42-\mathrm{V}$ hybrid applications. A series of thermal studies were conducted in FY07 to evaluate the thermal impacts of various coolant types, flow rates, insulation, and power loads (geometric cycles and drive profiles). The vehicle power load profiles for the $42-\mathrm{V}$ module were developed based on both vehicle simulation and dynamometer data.

The Saft 42-V module with active liquid cooling showed excellent thermal performance. The average cell temperature rise was less than $5^{\circ} \mathrm{C}$ for typical $42-\mathrm{V}$ mild hybrid applications such as in the Saturn Vue Green Line Hybrid. In more aggressive profiles using maximum current limits, the average cell temperature rise was less than $10^{\circ} \mathrm{C}$, which is still reasonable. Additionally, the temperature uniformity (cell-cell variations) was better than $2^{\circ} \mathrm{C}$. Flow studies showed that the design glycol/water coolant flow rate might have been higher than needed. The temperature from various drive cycles was bounded between the USABC 50Wh profile at the lower end and the NREL 75-amp charge neutral profile at the upper end. The NREL charge neutral 250 -amp/40-amp (discharge/charge) cycle provided an upper limit for aggressive cycling. With the module insulated (simulating its placement in a confined space in a vehicle) the average cell terminal temperature rose by less than $2^{\circ} \mathrm{C}$ relative to non-insulated tests. Although air cooling might have been sufficient under most driving loads, liquid cooling provides excellent thermal performance and the option of placing the module in most locations in a car, particularly in sealed areas.

(a)

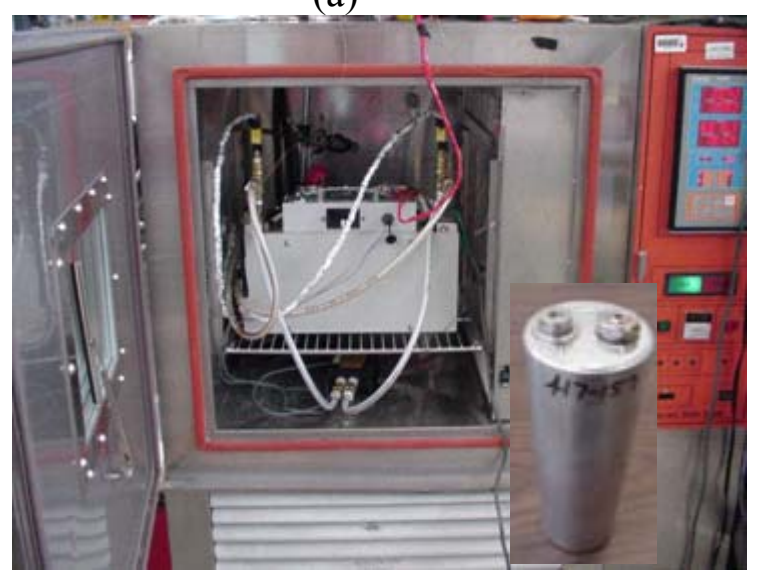

(b)

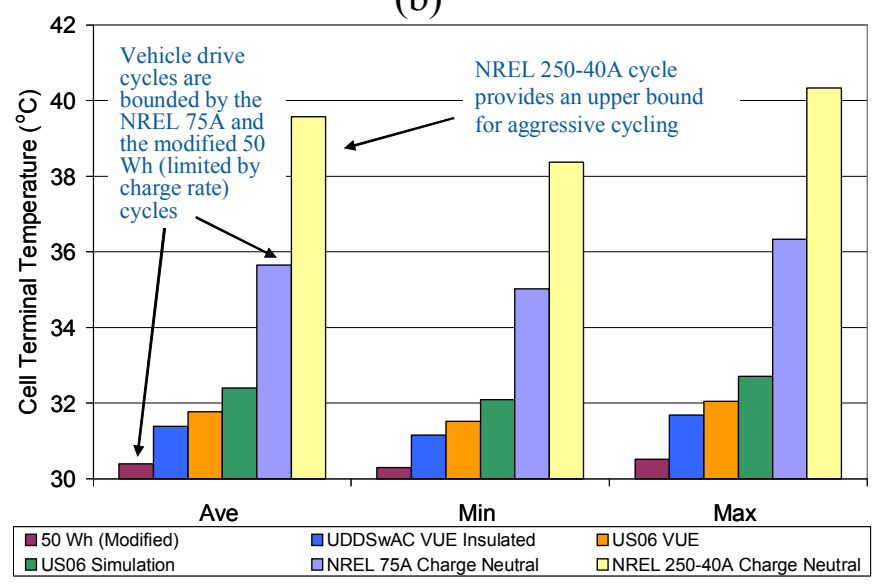

Figure 4. (a) Saft VL20P 42-V module in the environmental chamber used for testing. (b) Comparison of cell terminal temperatures for several drive cycles with ambient and coolant temperatures at $30^{\circ} \mathrm{C}$. 
Started Fabricating a Large Calorimeter for Thermal Testing of PHEV Modules Understanding and control of temperature is necessary to successfully operate battery packs in hybrid vehicles. Advanced battery chemistries such as lithium-based batteries are sensitive to the operating temperature. It is imperative to vehicle operation to understand the heat generation of the energy storage system. This includes battery interconnects and consideration of the efficiency differences between individual batteries within a battery pack. Currently, NREL has a calorimeter that measures heat generation from small "air-cooled" HEV modules and cells. In FY 2006, we identified the need for a larger calorimeter not only to increase our ability to increase testing more prototypes, but also to test larger, liquid-cooled modules that are expected to become available for plugin hybrid electric (PHEV) applications. We have also identified the need to measure heat generation from modules that are liquid cooled, a capability missing in our present calorimeter. We initiated designing and specifying components of the new calorimeter. During FY 2007, we designed and largely completed construction of the larger calorimeter. The new calorimeter has a test cavity measuring $60 \mathrm{~cm} \mathrm{x} 40 \mathrm{~cm} \times 40 \mathrm{~cm}$, almost 7 times larger than the existing calorimeter. The new calorimeter can measure heat rates up to $1 \mathrm{~kW}$, almost 10 times greater than the existing calorimeter. During the fiscal year, most of the components of the calorimeter were fabricated: 1) test chamber, 2 ) refrigeration system, 3) isothermal bath, and 4) external housing. The test chamber is the most critical component of the calorimeter because it measures battery heat generation accurately. The calorimeter will be commissioned and validated, and testing of FreedomCAR batteries will begin in mid FY 2008.

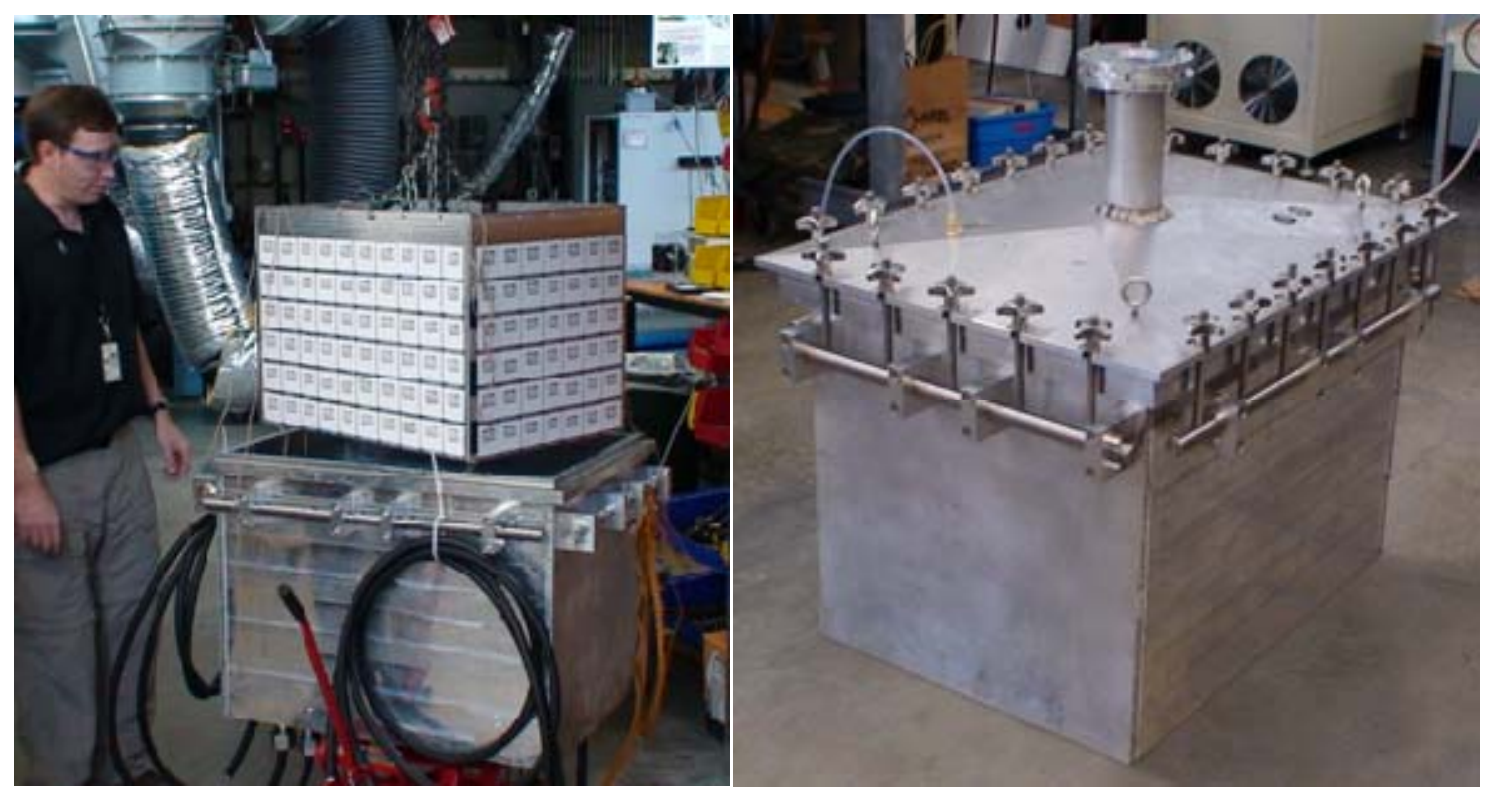

Figure 5. Internal enclosure of test chamber with heat flux measuring sensors being placed in the external enclosure of test chamber (left). Completed test chamber for the large calorimeter (right). 
Evaluated Phase-Change Material for Use in Thermal Management of Hybrid Battery Systems - Using phase-change material (PCM) for battery thermal management has promising benefits, such as passively buffering against life-reducing high battery operating temperatures and excessive temperature imbalance. With a focus on HEV and PHEV applications, NREL developed both a system-level and a component-level model for evaluating PCM thermal management and initiated testing on a prototype module provided by AllCell ${ }^{\circledR}$ Technologies LLC. The prototype module consists of commercial 18650 (1.5-Ah cobalt-oxide) Li-Ion cells surrounded by a graphite matrix that is impregnated with "wax" which changes phase (solid to liquid) between approximately $52^{\circ} \mathrm{C}$ and $55^{\circ} \mathrm{C}$. As part of the study, tests were conducted initially on the 18650 cells to measure electrical and thermal performance (thermal imaging, heat generation, and efficiency). The efficiency of the cell was measured in the calorimeter to be $92 \%$ for a charge sustaining geometric cycle at $30^{\circ} \mathrm{C}$ and $50 \%$ SOC. NREL researchers instrumented a prototype module to measure current, voltages, and temperatures (at 20 locations). Experimental results from testing the module in an environmental chamber were used to validate the analytical model developed to simulate the module's thermal behavior. Modeling enables practical evaluation of numerous vehicle operating scenarios and permits comparison of the $\mathrm{PCM} /$ graphite method to other thermal management approaches. It can also be used to explore potential design improvements.

(a)

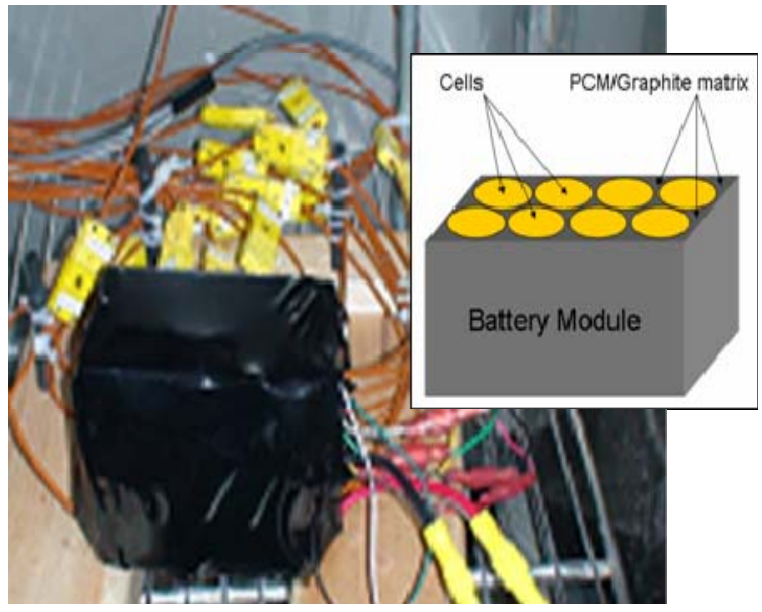

(b)

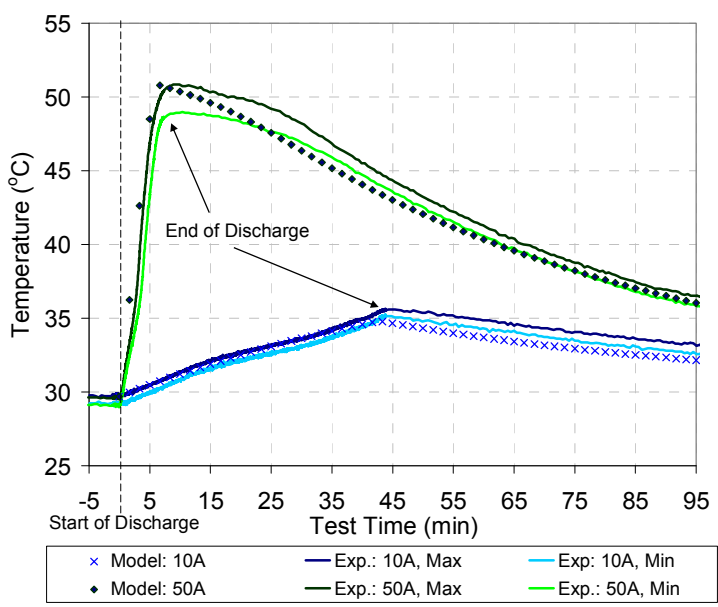

Figure 6. (a) Conceptual schematic of the prototype module design and picture of the instrumented AllCell PCM module in an environmental testing chamber.

(b) Validation of model with experimental data at different constant discharge rates.

Analysis conducted in FY07 indicates that the PCM/graphite matrix can effectively limit the peak temperature reached in the cells during short periods of intensive battery use. However, the PCM by itself is not a cooling method; in the absence of an active cooling system, continuous cell heat generation over substantial driving distances would fully melt the PCM and then continue to raise the temperature of the battery module. While the active cooling system must still be designed to handle the highest continuous thermal load expected, adding PCM could offer several important benefits. Using PCM could 
reduce the size of the active cooling system needed to handle peak intermittent thermal loads. It could reduce the need to limit power output in high temperature conditions. And it could potentially reduce exposure to momentary or localized high cell temperatures. Multidimensional modeling of the PCM matrix design also indicates that the high thermal conductivity of the matrix could improve temperature uniformity and limit thermal runaway propagation from an interior cell (by quickly distributing the generated heat away from the neighboring cells). Continued evaluation into FY08 will further confirm the above findings and allow NREL to investigate the benefits and drawbacks of the PCM design under cold and variable temperature conditions.

(a)

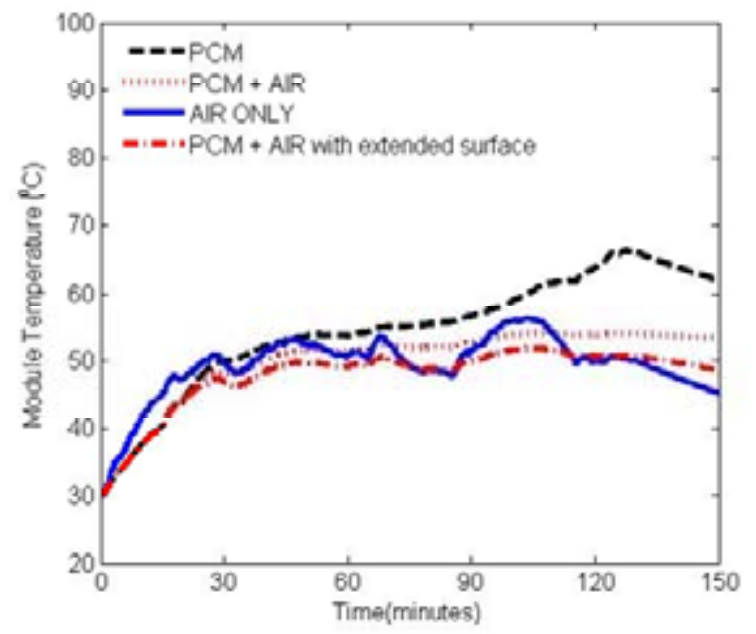

(b)

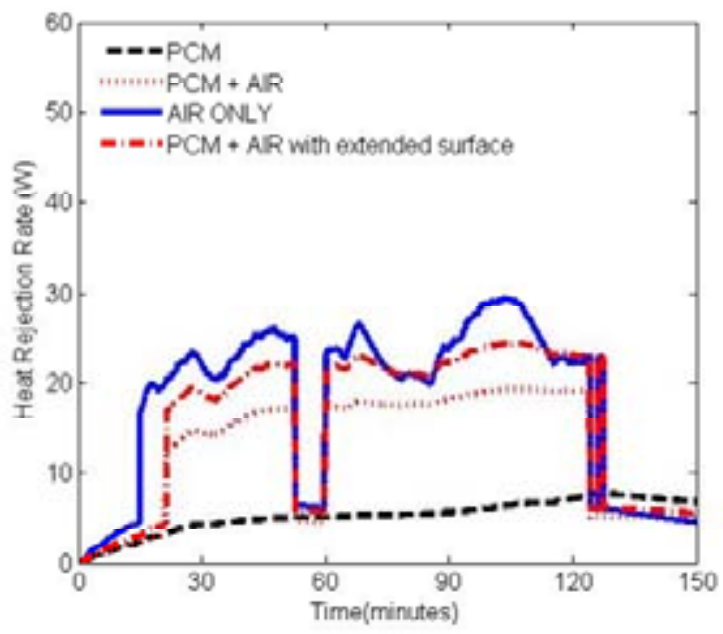

Figure 7. Performance comparisons of (a) battery temperature variations and (b) heat rejection rates for different thermal management methods in 'real-world' HEV driving

Quantified the Impacts of Design Parameters on Performance of Battery Thermal Management Systems - Battery thermal management is critical in achieving performance and extended life of batteries in electric and hybrid electric vehicles because temperature is one of the most significant factors impacting battery performance and life. Therefore, the battery must be carefully managed to minimize degradation and the impact that such degradation can have on vehicle performance and fuel consumption. Designing more effective, simpler, and less expensive thermal management approaches will assist in the further development of affordable battery packs and increased market penetration of HEVs and PHEVs. Appropriate modeling for predicting thermal behavior of battery systems in vehicles helps to make decisions for improving design faster. The purpose of this study was to identify analyses and approaches that engineers should consider when they design a battery thermal management system for vehicles.

Choice of coolant in a convective cooling system has significant design implications. Air cooling systems of batteries are simpler than liquid cooling systems. However, air systems have a relatively smaller heat transfer coefficient at the cooling object surface because of the lower thermal conductivity of air. In addition, small heat capacity of air 
would cause difficulty in achieving temperature uniformity inside a cell or between cells in a module. Liquid cooling systems transfer heat more effectively (because of higher heat transfer coefficients and higher heat capacity) and take up less volume than air systems and are more flexible for placement in vehicle, but their added complexity and cost may outweigh the merits.

In air cooling, the surface heat transfer coefficient, $\mathrm{h}$, and the blower power are sensitive to the hydraulic diameter of the channel $\left(D_{h}\right)$. On the other hand, $h$ evaluated at cell surface is not as sensitive to the variation of $\mathrm{D}_{\mathrm{h}}$ in a water and glycol jacket cooling system because of the added thermal resistances of jacket thicknesses. Results of computational fluid dynamics model simulation imply that capturing the internal heat flow paths and thermal resistances inside a cell using a sophisticated three-dimensional cell model are important for the improved prediction of cell/battery thermal behaviors. Although air cooling might be sufficient under most driving loads, liquid cooling provides more effective thermal performance. It also allows the option of placing a battery pack module in most locations in a car, particularly in sealed areas. Larger PHEV packs may require liquid cooling for more uniform temperature distribution.

(a)

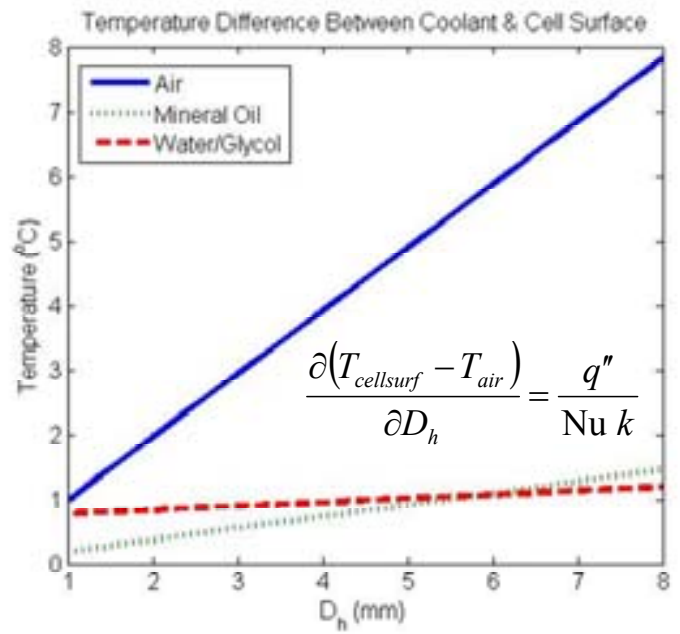

(b)

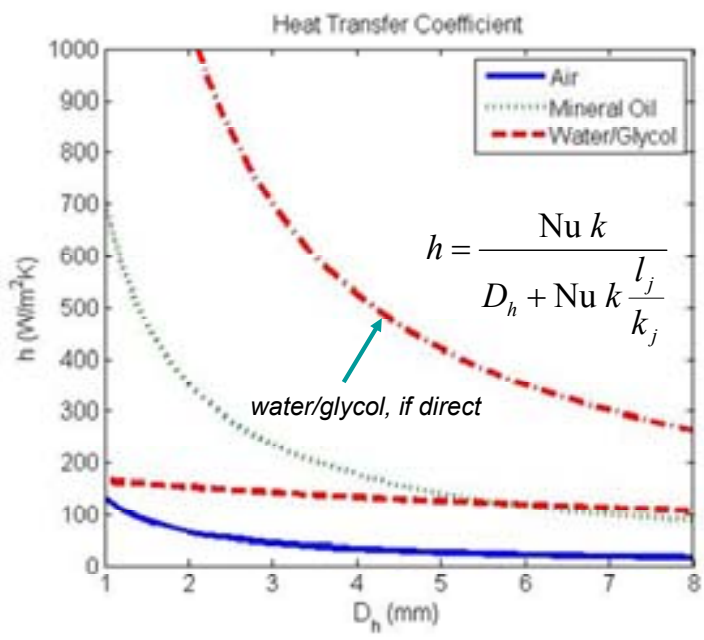

Figure 8. Steady state laminar channel flow relations. Differences in sensitivity of thermal parameters between liquid cooling and air cooling. (a) shows the temperature difference between coolant and cooling surface and (b) shows heat transfer coefficients at the cooling surface as a function of the hydraulic diameter of the channel.

Initiated Development of a Three-Dimensional Lithium-Ion Battery Performance Model - In high energy battery packs for PHEV or EV applications, large-format cells are preferable to small cells because they require fewer electrical interconnections and less monitoring and balancing circuitry. However, the spatial imbalance of electrochemically important quantities such as temperature and electric potential becomes more severe inside large-format cells than inside small cells. This could affect the life and performance of cells. NREL researchers initiated development of a three-dimensional cell 
model to provide methodology for examining thermal-chemical-structural interactions on the performance and life degradation of lithium-ion batteries. The goal of this modeling is to support thermal modeling of batteries both during normal and abusive conditions.

The model captures both the storage and the release of electric energy through chemical reactions. It also considers temperature and chemical species transport to the reaction sites, which are important factors for determining electrochemical performance and lifereducing side reactions in a battery. Because the spatial distributions of temperature and electric potential inside a cell are significantly affected by decisions made during cell design, it is critical to understand the impacts of battery design variables on them and capture them in the model. One of the difficulties for three-dimensional modeling is resolving micro-scale layered electrode structures in a computational grid system across the much larger cell dimension scale. NREL researchers have developed a multi-scalemulti-dimensional model and used it to evaluate a typical PHEV battery. Initial results indicated that there could be significant cell-internal temperature imbalance and consequent non-uniform use of materials through a cell under aggressive cycling conditions. NREL will improve the model in FY08 and will interact with other national laboratories and industry and aid developers in resolving issues arising from the scale up of small cells into large-format vehicle-ready cells.

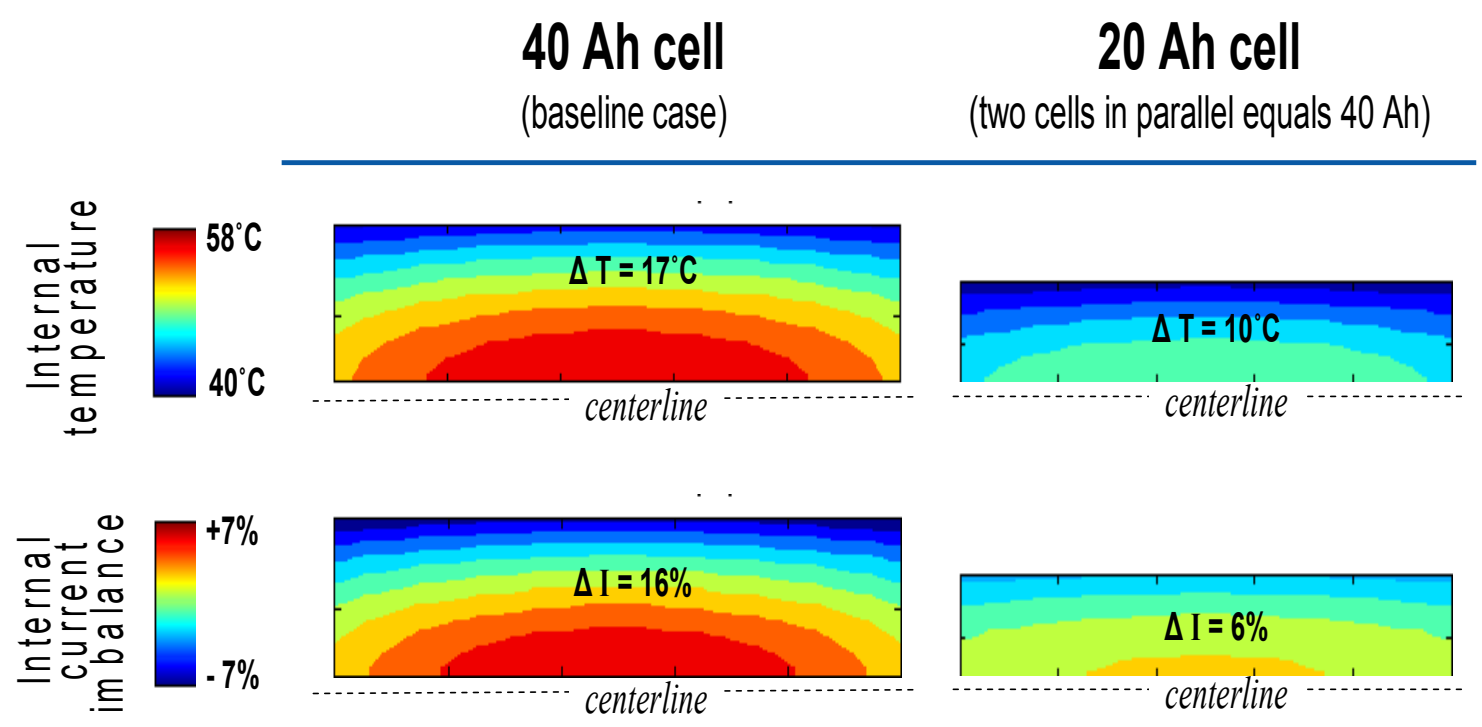

Figure 9. Steady state internal temperature and current distributions in PHEV cylindrical cells under an aggressive cycling condition. The 40-Ah cell, with $17^{\circ} \mathrm{C}$ internal temperature imbalance and $16 \%$ current imbalance, will have significantly shorter life compared to a battery design combining two smaller 20-Ah cells in parallel with $10^{\circ} \mathrm{C}$ internal temperature imbalance and $6 \%$ current imbalance . 


\subsection{Simulation and Requirements Analysis Activities}

Analyzed Impact of Energy Window Size on Fuel Economy of Power-Assist HEVs - In response to questions from the Energy Storage Tech Team and USABC Managing Committee, NREL engineers studied the impact of battery energy window usage on fuel consumption for a minimum power-assist midsize hybrid car. The major purpose was to revisit the 300-Wh USABC available energy requirement for power-assist HEVs. NREL researchers simulated vehicles with a range of battery capacities over several test and drive cycles and observed the trend between the varying in-use energy window during the test cycle and the fuel savings achieved. The sensitivity of the results to different degrees of vehicle hybridization and different control parameter tunings were also studied. In all cases, the HEV fuel savings increase with larger energy windows, but the returns eventually diminish. With charge-sustaining operation, the simulated HEVs achieved considerable fuel savings with an energy window on the order of $50 \mathrm{Wh}$, and captured most additional fuel savings from window expansion out to $150 \mathrm{Wh}$.

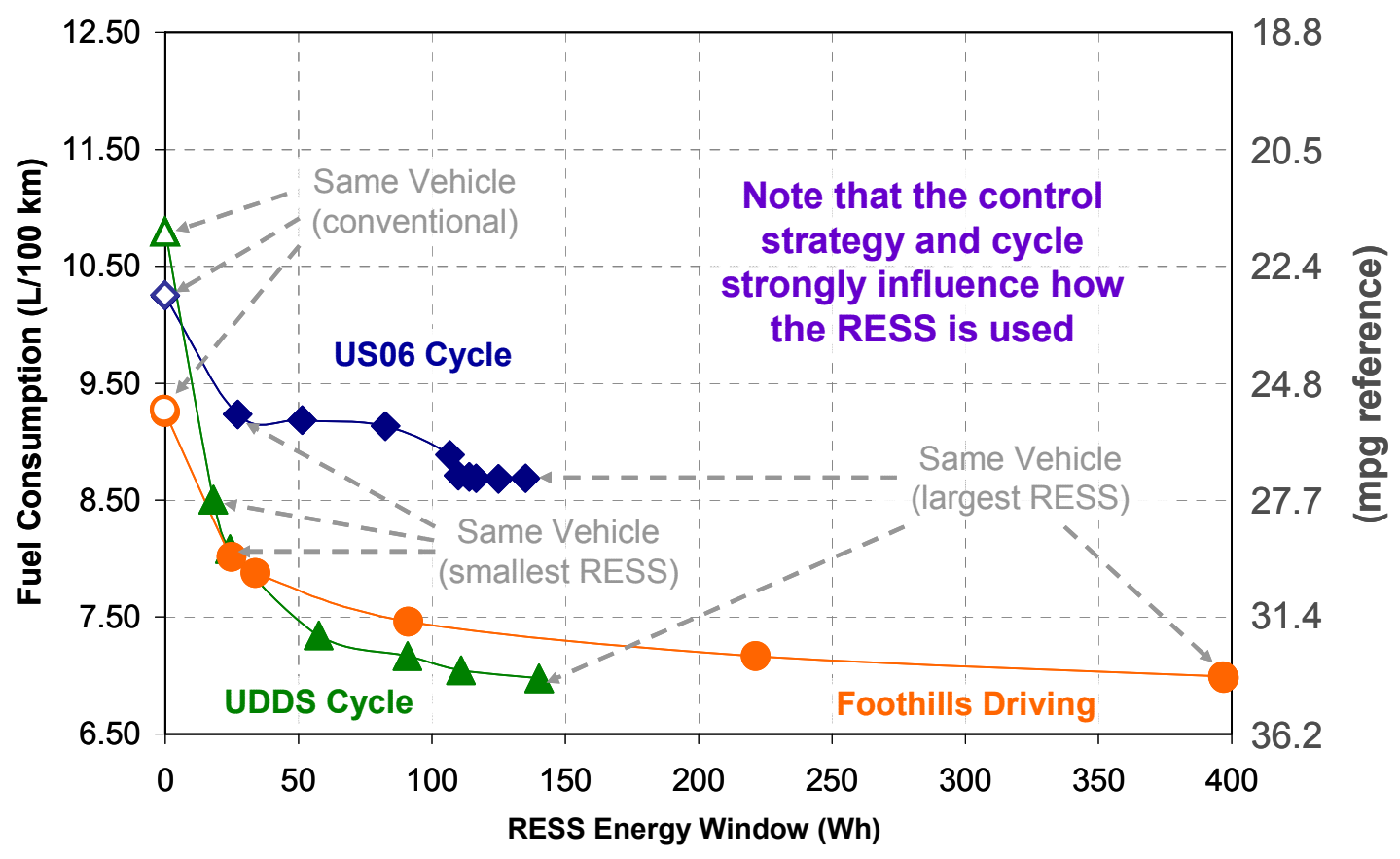

Figure 10. Simulation results for different rechargeable energy storage system (RESS) vehicle cases over three different drive cycles.

To support the simulation results with real data, NREL also analyzed the energy window used by existing commercial hybrids on a number of test and drive cycles. The vehicles examined included the Ford Escape hybrid, the Toyota Prius and Camry hybrids, and the Honda Accord hybrid. Analysis of the dynamometer and road test data confirmed that even hybrids with large batteries used energy windows smaller than $200 \mathrm{Wh}$ for chargesustaining operation on the standard test cycles. Based on the simulation and test data 
analysis, we observed that while fuel savings can be increased by expanding the energy window, the resulting savings need to be weighed against the expense of using larger batteries and the life implications of widening the battery's defined SOC limits. Conversely, the size and cost advantages of relaxing the energy storage requirement for an HEV should be weighed against both the anticipated fuel consumption and performance penalties. It should be noted that the performance impact of smaller HEV energy windows (such as limiting acceleration assistance or idle-off air conditioning performance) was not considered for this study and could be a factor in the final selection of the energy window. The results of this study were shared and discussed with the Energy Storage Tech Team and USABC.

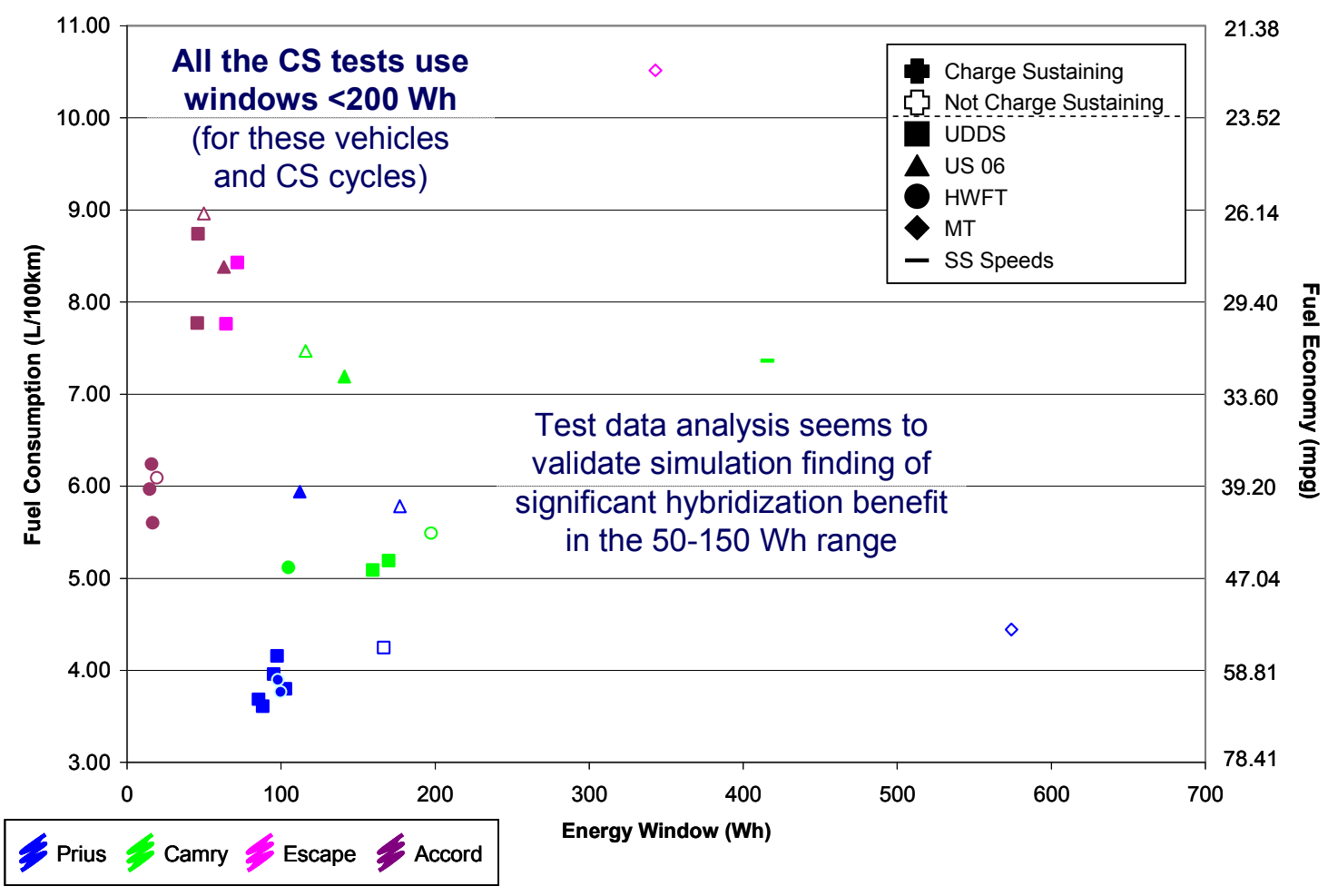

Figure 11. Test data analysis for four commercial hybrids over several test cycles: the Urban Dynamometer Driving Schedule (UDDS), US06 profile, Highway Fuel Economy Test (HWFT), a mountain trace (MT), and steady-state (SS) speed testing. All charge-sustaining (CS) tests for these vehicles and cycles use energy windows smaller than 200 Wh (Camry and Accord data provided by ANL).

Developed an Approach for PHEV Battery Performance, Life, and Cost Tradeoff Analysis - Battery technology is critical to the operation and success of PHEVs. Battery models linked with vehicle system simulation are typically empirical equivalent circuit models based on test data. This type of model is suitable for fast simulation but provides limited connection to physical battery design parameters such as electrode geometry and electrode materials and to the internal electrochemical characteristics of the battery module and cell. For PHEVs, life and cost of the battery modules are important factors affecting potential market penetration. The goal of this project was to review available 
models for battery performance, cost, and life and to come up with an approach for interconnecting those models to parametrically explore the impact of battery design parameters for a PHEV application. This includes characterizing the cell performance, completing vehicle system simulations, and finally, estimating system cost and life. The optimal battery design would satisfy life goals while meeting performance constraints at a reasonable cost.

Battery cost is a function of the life requirements, the cell materials, manufacturing methods, and cell design. Battery life is a function of the electrochemistry, usage pattern, and cell design. The cell design is a function of the performance requirements. These intertwined relationships can be explored using robust models and automated design of experiments tools. Previous study at NREL suggested that long-term PHEV incremental cost would be between $\$ 5,000$ and $\$ 10,000$, of which most is battery cost. To achieve market penetration without substantial government incentives, the battery cost must be reduced. This project explores the battery design space/parameters to highlight potential design scenarios that provide cost reduction and fuel savings for a PHEV. Three battery performance models are being developed or are available for use in these analyses. The first is a State Variable Model: a reduced order model of the fundamental electrochemical equations. The key added values of the model are the availability of information on the cell internal design, provision of internal concentration gradients, and fast run timewhich allows co-simulation with vehicle systems models. To extend life, it is critical to accurately limit operation not on bulk attributes, but on the specific local internal conditions. The other models are 1D and 3D full electrochemical models that, solved by finite volume method, are also available. They are too slow to connect to vehicle system simulation, but do provide the ability to sweep a wide battery design parameter space and screen for potential good PHEV battery candidates.

Models for battery cost and life were challenging to identify. In FY07, a simple model was developed for evaluation of the overall trade-off analysis, but in FY08 we intend to use a simplified version of the USABC cost model. For life modeling, a stress accumulation approach was considered and will be further developed and refined in FY08. The combined efforts of this task provide an interconnected suite of battery and vehicle models that will be used to identify new battery design options with the potential to maximize the petroleum displacement value of PHEVs at a reasonable cost.

Supported Identification of Energy Storage Requirements for PHEVs - NREL engineers supported DOE and FreedomCAR Tech Teams in articulating the rationale and approach for defining the energy storage requirements for PHEVs. In support of the USABC PHEV Battery Workgroup (a task force within the Energy Storage Tech Team), NREL and Argonne National Laboratory performed analysis to identify PHEV battery requirements. The analysis process included defining vehicle platforms, vehicle performance targets, the desired equivalent electric range operating strategy (all-electric or blended), and the state-of-charge window. Based on the analysis, USABC members recommended two categories of batteries: one for a 10-mile equivalent electric vehicle (EV) range (high power/energy ratio) and one for a 40-mile EV range (high energy/power ratio). Four sets of requirements were defined: (1) system-level (range, 
pack cost, calendar life, volume, weight, energy efficiency); (2) charge-depleting mode (2-second and 10-second discharge power, 10-second regenerative braking power, available energy at constant power, number of deep cycles, maximum recharge rate); (3) charge-sustaining HEV mode (available energy for charge-sustaining operation, cold cranking power, number of shallow charge-sustaining cycles); and (4) battery limits (maximum current, maximum and minimum voltage, operating and survival temperatures). The resulting requirements were adopted by USABC. With input from USABC and DOE program managers, NREL wrote and submitted a paper to the $23^{\text {rd }}$ Electric Vehicle Symposium summarizing the rationale, assumptions, analysis, discussions, and resulting requirements.

\section{Table 1. USABC Battery Requirements for Plug-in Hybrid Vehicles}

\begin{tabular}{|c|c|c|c|}
\hline Characteristics at EOL (End of Life) & & $\begin{array}{c}\text { High Power/Energy Ratio } \\
\text { Battery }\end{array}$ & High Energy/Power Ratio Battery \\
\hline Technology Readiness Target & year & 2012 & 2016 \\
\hline Reference Equivalent Electric Range & miles & 10 & 40 \\
\hline Maximum SystemProduction Price @ 100,000 units/year & $\$$ & $\$ 1,700$ & $\$ 3,400$ \\
\hline Calendar Life, $35^{\circ} \mathrm{C}$ & year & 15 & 15 \\
\hline Maximum System Weight & $\mathrm{kg}$ & 60 & 120 \\
\hline Maximum System Volume & liter & 40 & 80 \\
\hline Peak Pulse Discharge Power - $2 \mathrm{~s} / 10 \mathrm{~s}$ & $\mathrm{~kW}$ & $50 / 45$ & $46 / 38$ \\
\hline Peak Regen Pulse Power (10s) & $\mathrm{kW}$ & 30 & 25 \\
\hline Available Energy for CD (Charge Depleting) Mode, $10 \mathrm{~kW}$ Rate & $\mathrm{kWh}$ & 3.4 & 11.6 \\
\hline CDLife/ Discharge Throughput & cycles/MMh & $5,000 / 17$ & $5,000 / 58$ \\
\hline System Recharge Rate at $30^{\circ} \mathrm{C}$ & $\mathrm{kW}$ & $1.4(120 \mathrm{~V} / 15 \mathrm{~A})$ & $1.4(120 \mathrm{~V} / 15 \mathrm{~A})$ \\
\hline Available Energy for CS(Charge Sustaining) Mode & $\mathrm{kWh}$ & 0.5 & 0.3 \\
\hline Minimum Round-trip Energy Efficiency (USABC HEV Cycle) & $\%$ & 90 & 90 \\
\hline Cold Cranking Power at $-30^{\circ} \mathrm{C}, 2 \mathrm{~s}-3$ pulses ( $10 \mathrm{~s}$ rest between) & $\mathrm{kW}$ & 7 & 7 \\
\hline CSHEV Cycle Life, 50 Wh Profile & cycles & 300,000 & 300,000 \\
\hline Maximum Operating Voltage & Vdc & 400 & 400 \\
\hline Minimum Operating Voltage & Vdc & $>0.55 \mathrm{x}$ Vmax & $>0.55 \mathrm{x}$ Vmax \\
\hline Maximum Self-Discharge & Wh/day & 50 & 50 \\
\hline Unassisted Operating \& Charging Temperature Range & ${ }^{\circ} \mathrm{C}$ & -30 to +52 & -30 to +52 \\
\hline Survival Temperature Range & ${ }^{\circ} \mathrm{C}$ & -46 to +66 & -46 to +66 \\
\hline
\end{tabular}

\subsection{Industry and International Support Activities}

Supported FreedomCAR Technical Team and Battery Developers - NREL continued analysis of energy storage requirements for power-assist hybrid vehicles, ultracapacitormild-hybrid vehicles, and plug-in hybrid electric vehicles for the USABC Energy Storage Technical Team. The support includes performing necessary analysis and participation and discussion at various workgroups. In additions, NREL engineers participated at various workgroups to review and support FreedomCAR battery developers including JCS and CPI/LG Chem. In FY08, in addition to JCS and CPI/LG Chem, we plan to support A123 Systems and EnerDel.

DOE/NREL Supported Several IEA Hybrid Electric Vehicle Agreements Annexes With funding from the DOE Energy Storage Program, NREL provided support to 
International Energy Agency (IEA) hybrid vehicle activities through an IEA Implementing Agreement (IA) for Annex VII (Hybrid Electric Vehicles), Annex XII (Heavy Duty Hybrid Vehicles) and Annex XIII (Fuel Cell Vehicles). During FY 2007, with support of DOE/NREL funding, the HEV IA Annex prepared and distributed its 2006 annual report to the international community. The report describes the annexes and presents the activities on hybrid and electric vehicles in each member country. In addition, NREL, as one of the U.S. expert representatives, participated at the Annex XII kick-off meeting in San Diego, California, in February 2007 and then provided input to a work plan. NREL also participated at the kick-off meeting of Annex XIII in Graz, Austria, in September 2007 as the U.S. expert representative. These activities foster international collaborations on energy storage and hybrid vehicle technologies among member countries.

Future Directions - In FY 2008 and future years in the thermal management area, NREL will perform thermal analysis of cells and modules for FreedomCAR battery developers; use the advanced calorimeter for measuring heat generation from liquid-cooled modules; and measure thermal properties of energy storage devices in order to improve thermal performance of batteries and ultracapacitors. The focus of our work will be with FreedomCAR/USABC battery developers such as A123 Systems and EnerDel and PHEV battery developers such as JCS and CPI/LG Chem. In the energy storage simulation area, we will continue to develop battery and ultracapacitor electrical models for vehicle simulators and perform analysis on those models. We will also continue to develop the process and battery cost/life/performance models for PHEV battery tradeoff analysis. NREL will work with USABC and the Energy Storage Tech Team to review requirements and targets for energy storage systems for hybrid electric vehicles. In these and other activities, NREL will work closely with DOE program managers, USABC original equipment manufacturer representatives, and FreedomCAR battery developers to ensure that our activities and deliverables add value to each aspect of the Energy Storage Program.

\section{Applied Battery Research}

Developed Thermal Runaway Models for Improving Abuse Tolerance of Lithium-Ion Cells and Modules - The growing interest in lithium-ion batteries for use in advanced vehicle applications makes understanding abuse tolerance more urgent. In FY06, NREL developed three-dimensional models to simulate thermal runaway in lithium-ion cells by capturing chemical reactions, associated heat releases, and heat rejection from the cell exterior. Chemical reactions at elevated temperatures in lithium-ion batteries were formulated in Arrhenius type reactions. In FY07, the model was further refined and demonstrated the three-dimensional effect of chemical reactions and associated heat flow in abuse conditions such as internal short circuit events. In addition, NREL researchers developed a model that can address cell-to-cell interaction and the propagation of thermal runaway in a battery module or pack. From the viewpoint of thermal runaway propagation, the cells in a module are dispersed chemical and heat sources, and they are thermally connected through various heat transfer paths. We concluded that thermalrunaway propagation is determined by the competition between heat dissipation through 
the thermal network in a module and localized heat generation. Researchers explored how design features such as cell size, type of heat conduction medium, cell interconnects, and thermal contact between cells affect abuse tolerance of a module. A design slowing down the concentrated heat delivery and accelerating the distributed heat transfer in a module is favorable for constructing a thermal-runaway-propagation-resistive battery system.

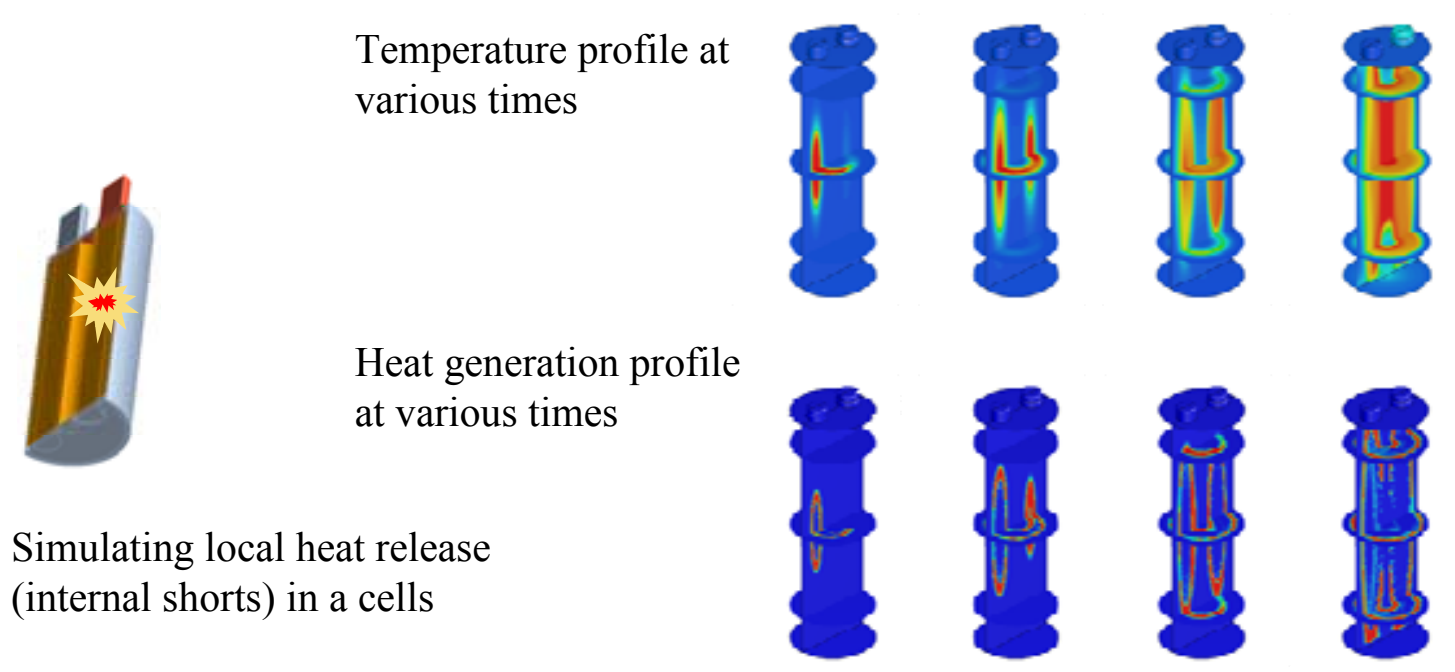

Figure 12: Results of chemical-thermal modeling of lithium-ion battery thermal runaway: cell-internal abuse reaction propagation during internal short circuit event
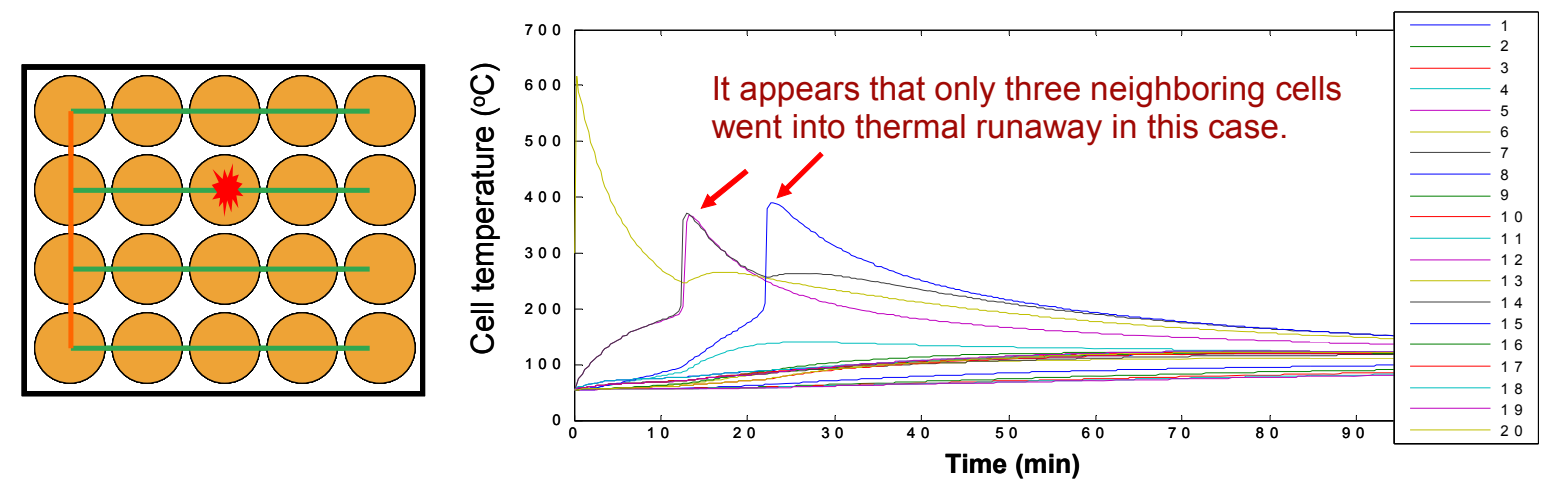

Figure 13: Thermal runaway propagation through a module after the red-marked cell goes into thermal runaway (left), three cells going into thermal runaway in this particular configuration as depicted by curves going into extreme temperatures.

Future Directions - In FY08 and future years, NREL will continue to enhance the model capability by: validating the design with experimental data from other national laboratories, extending the model to address various chemistries, and incorporating a thermally coupled electrochemistry model into the three-dimensional cell model. The models will be valuable tools for helping developers to evaluate various cell and module designs in their pursuit of developing safe and abuse-resistant lithium-ion batteries. 


\section{Focused Long-Term Research}

Investigated Use of Molybdenum Oxide Nanoparticles as Improved Li-Ion Electrodes In support of the Focused Long-Term Battery Research Program, also called the BATT or Batteries for Advanced Transportation Technologies program, NREL performs research to develop next-generation materials for improved lithium-ion battery electrodes. Lithium-ion batteries are current power sources of choice for portable electronics offering high energy density, flexibility, and longer lifespan than comparable technologies. Significant and simultaneous improvements in power, energy density, and durability for inexpensive, safe technologies may enable utilization in hybrid electric vehicles. Therefore, the objective of NREL's effort has been to develop improved electrode materials that could simultaneously meet all of the requirements for vehicular applications. The fabrication of durable electrodes made from inexpensive, benign, nanostructured materials with high capacity and rate capability was thus initiated. Additionally, first-principles molecular dynamics simulations were performed to understand the Li-ion insertion mechanism in promising nanostructured anode and cathode materials as well as to predict alternative optimal metal oxide nanostructures for Li-ion electrode applications.

Crystalline molybdenum oxide $\left(\mathrm{MoO}_{3}\right)$ nanoparticles were grown at high density by the potentially economical hot-wire chemical vapor deposition (HWCVD) technique. Furthermore, the particle size and morphology were specifically tailored by varying the synthesis conditions - reactor temperature and pressure, filament type and temperature, and gas composition. Then electrophoresis deposition was used to fabricate high surface area nanoparticle electrodes from the nanoparticles. The electrodes were tested in a halfcell configuration with lithium as the counter electrode. Crystalline $\alpha$-phase $\mathrm{MoO}_{3}$ nanoparticle negative electrodes exhibited a surprising reversible capacity of $630 \mathrm{mAh} / \mathrm{g}$ and high rate capability, delivering $\sim 500 \mathrm{mAh} / \mathrm{g}$, at $2 \mathrm{C}$ rate, where $\mathrm{C}$ is rated capacity. The nanoparticle negative electrodes show no degradation in capacity for 150 deep cycles at $\mathrm{C} / 2$ rate with an average Li-extraction potential of $\sim 1.5 \mathrm{~V}$. Electrodes tested with micron-sized $\mathrm{MoO}_{3}$ particles showed signs of failure after several cycles under the same test conditions. Theoretical calculations elucidated the complex Li-ion insertion process and revealed a novel mechanism confirming the nanoscale, high-rate, reversible capacity.

When employed as the positive electrode, $\alpha$-phase $\mathrm{MoO}_{3}$ nanoparticle electrodes were shown to have a capacity of $120 \mathrm{mAh} / \mathrm{g}$ without any degradation, when cycled at $\mathrm{C} / 1$ rate for 1500 complete charge and discharge cycles. A positive electrode comprised of $\beta$ phase $\mathrm{MoO}_{3}$ nanoparticles was shown to have a higher initial capacity-about 225 $\mathrm{mAh} / \mathrm{g}$ at $\mathrm{C} / 1$ rate. Unfortunately, the $\beta$-phase electrode exhibited capacity fade upon cycling. Both the $\alpha$ - and $\beta$-phases had a relatively flat charge and discharge potential of about $2.5 \mathrm{~V}$. We did achieve a theoretical understanding of the formation mechanism for both phases. Additionally, predictive theory revealed that by incorporating tungsten into the $\beta$-phase $\mathrm{MoO}_{3}$ nanoparticles, the stability of the nanoparticles could be improved, and a higher capacity durable positive electrode might be realized. Preliminary proof of concept results showed that $\mathrm{HWCVD} \mathrm{Mo}_{1-\mathrm{y}} \mathrm{W}_{\mathrm{y}} \mathrm{O}_{3}$ particles containing approximately 35 atomic $\% \mathrm{~W}$ (percent of total number of atoms) yielded a material that could be 
significantly more stable than the $\beta$-phase $\mathrm{MoO}_{3}$ nanoparticles. Additionally, theoretical results showed that $\mathrm{Mo}_{1-\mathrm{y}} \mathrm{Ti}_{\mathrm{y}} \mathrm{O}_{3}$ nanoparticles had an increased charge/discharge potential of about $3.5 \mathrm{~V}$. Proof of concept experiments showed that $\mathrm{Mo}_{1-\mathrm{y}} \mathrm{Ti}_{\mathrm{y}} \mathrm{O}_{3}$ nanoparticles might be made with HWCVD. Thus, during FY07, we demonstrated improved electrode technologies employing $\mathrm{MoO}_{3}$, which is both an inexpensive and non-toxic material. Furthermore, theoretical calculations elucidated Li-ion insertion and extraction mechanisms as well as means to predict new optimized materials.
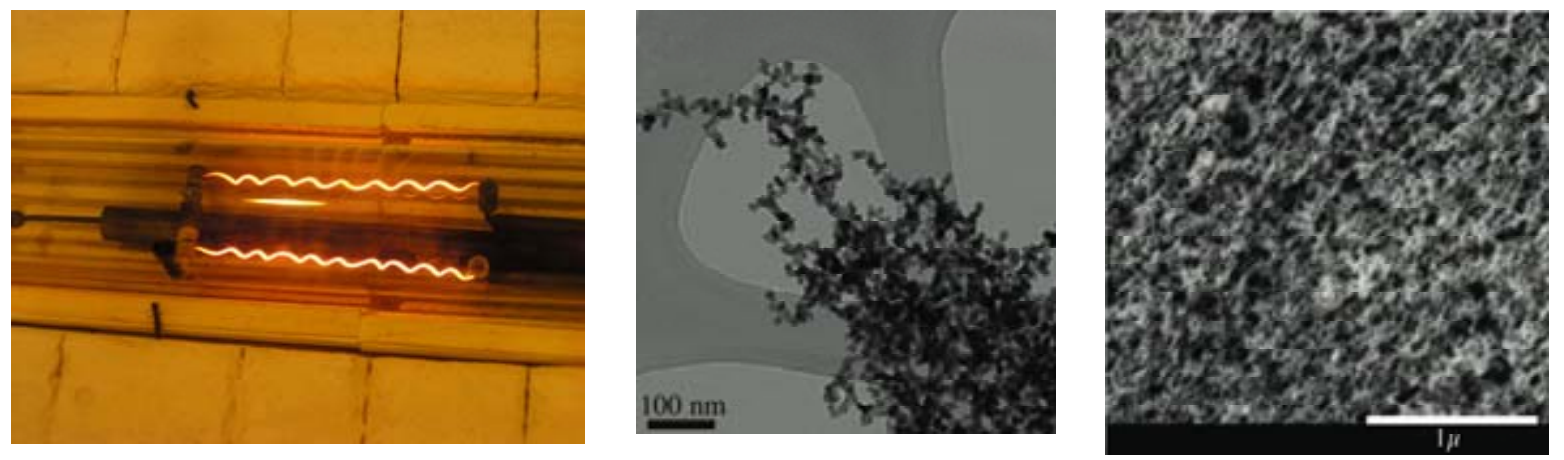

Figure 14. Photograph of molybdenum filament employed in HWCVD process (left image).Transmission electron microscope image of $\mathrm{MoO}_{3} \mathrm{HWCVD}$ nanoparticles (center image), Scanning electron microscope image of the high surface area porous nanoparticle film fabricated from electrophoresis (right image).
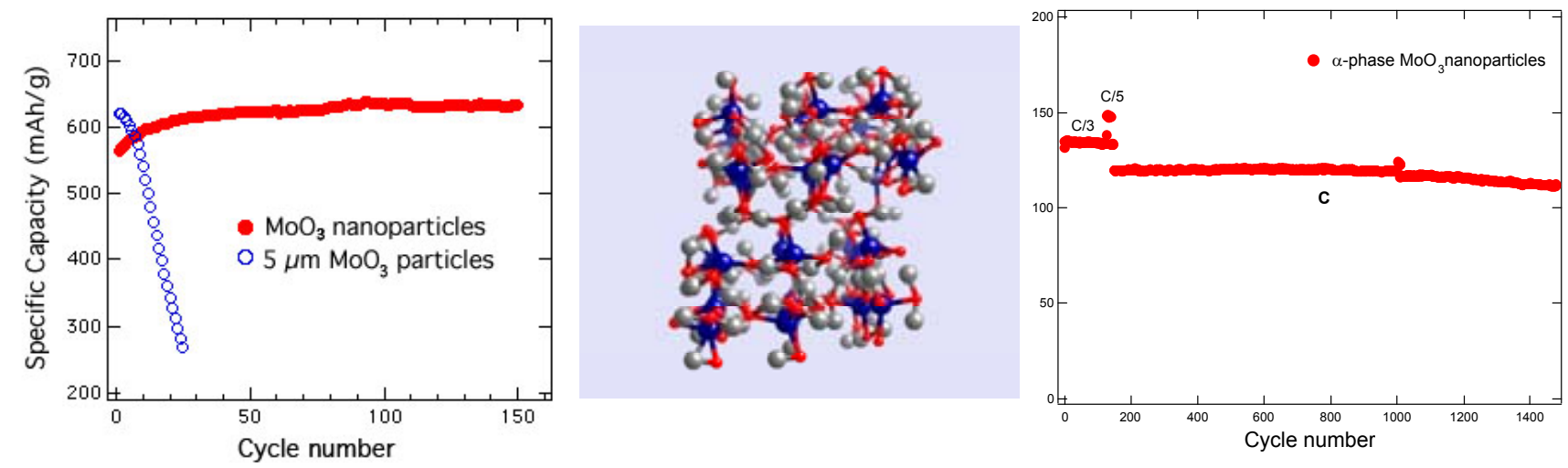

Figure 13. The cycling stability of the $\alpha$-phase $\mathrm{MoO}_{3}$ nanoparticle negative electrode compared to commercially available $\mu \mathrm{m}$-sized $\mathrm{MoO}_{3}$ particles cycled at $\mathrm{C} / 2$ rate (left image). Theoretical structure of a $\mathrm{MoO}_{3}$ nanoparticle following $\mathrm{Li}$-insertion with $\mathrm{Li}, \mathrm{O}$, and Mo represented by gray, red, and blue balls, respectively (center image.) Cycling stability of the a-phase $\mathrm{MoO}_{3}$ nanoparticle positive electrode with durable capacity exhibited at C/1 rate (right image).

Investigated Use of Ordered Titanium Oxide Nanotube Materials for Improved Li-Ion Electrodes - Structuring electrode materials on the nanoscale is one of the most promising approaches for advanced Li-Ion batteries with high capacities (energy densities) at significantly enhanced charge and discharge rates (power densities). NREL 
had previously investigated developing ordered $\mathrm{TiO}_{2}$ nanotubes for solar thin film applications. In the summer of FY07, NREL researchers received limited discretionary funds to explore the potential of $\mathrm{TiO}_{2}$ ordered nanotubes materials for use in lithium-ion cells.

NREL researchers prepared oriented arrays of $\mathrm{TiO}_{2}$ nanotubes (NT) on Ti metal substrate by using an electrochemical anodization technique. The resulting open-ended NT arrays were several micrometers in length with typical wall thicknesses and inter-tube spacing of $8-10 \mathrm{~nm}$ and pore diameters of $30 \mathrm{~nm}$. The as-deposited films were converted from an amorphous material to the $\mathrm{TiO}_{2}$ anatase crystalline phase by annealing at moderate temperatures. Electrochemical tests of the annealed $\mathrm{TiO}_{2} \mathrm{NT}$ films as an anode material against lithium in half cell showed that (1) repeated Li-Ion insertions and extractions had no effect on the morphology of the NTs (indicating that the arrays are structurally robust, as shown by scanning electron microscopy of tested samples); (2) the Li-storage capacity of the NT films was significantly larger than the theoretical capacity of the bulk material; and (3) the rate capability of NT films was more than 10 times larger than that of films consisting of substantially larger $\mathrm{TiO}_{2}$ particles $(\sim 300 \mathrm{~nm})$. A cycling stability study of one electrode showed some capacity loss, which was tentatively attributed to the detachment of some NTs from the conducting substrate. Adjusting the annealing conditions should improve the adhesion.

The initial results of using ordered titanium dioxide nanotube arrays in battery materials are encouraging and we plan further R\&D on ordered nanostructured electrodes using NREL internal discretionary funds. The eventual goal of this research is to develop the technological basis for high-power Li-Ion cathodes and anodes.
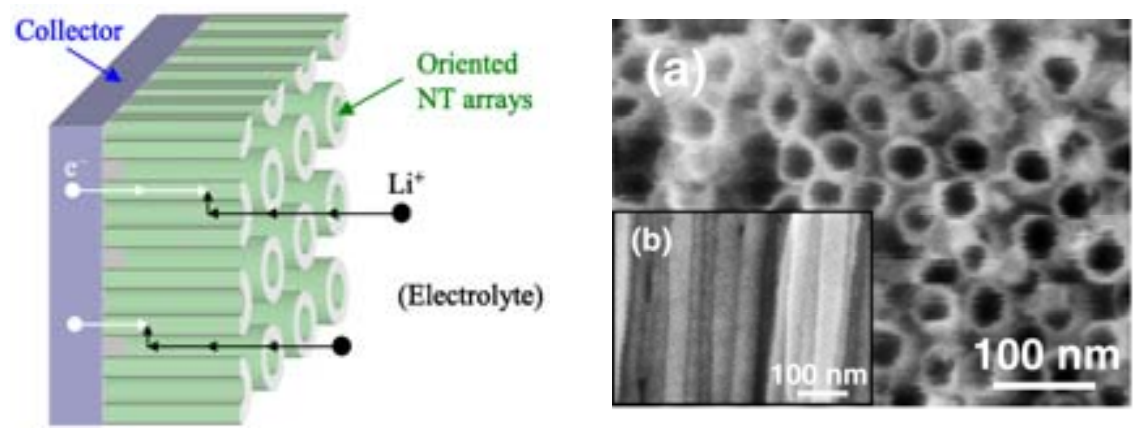

Figure 14. Schematic of oriented NT arrays as Li-Ion battery electrodes (left image) and scanning electron microscopy (SEM) images of (a) top and (b) bottom views of $\mathrm{TiO}_{2} \mathrm{NT}$ arrays (right image). 

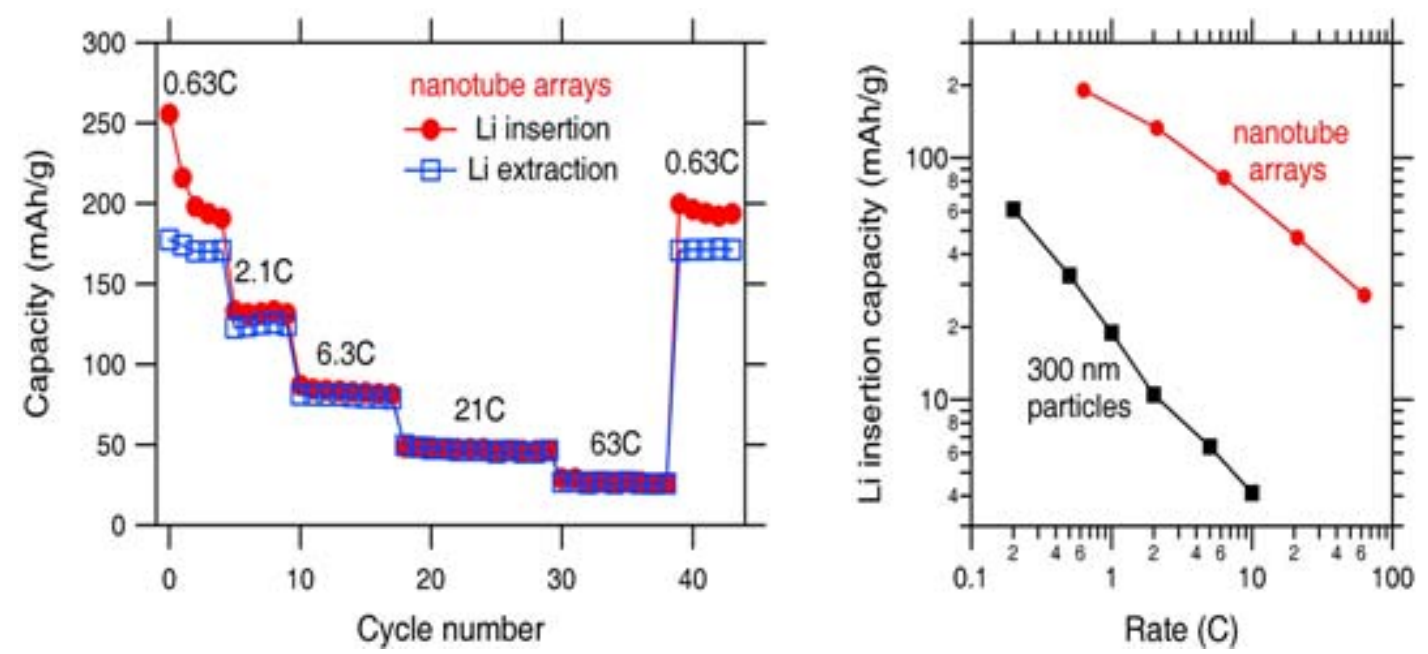

Figure 15. Rate capability of $\mathrm{TiO}_{2} \mathrm{NT}$ electrodes (left image). Comparison of their rate capability with that of electrodes composed of large $(300 \mathrm{~nm})$ particles (right image). Data for 300-nm particle films adapted from Maier et al, Adv. Materials. 19, 2087 (2007).

Future Directions - With regard to molybdenum oxide nanoparticle electrodes, our ultimate multi-year goal is to demonstrate a fully optimized anode for vehicular applications. The durable and inexpensive anode will have high capacity, operate at a desirable charge/discharge potential and temperature, and will be capable of high-rate pulses. Furthermore, degradation mechanisms and potential for economical scale-up and commercial application will be explored by working with the battery industry.

In FY08, our objective is to test the $\mathrm{MoO}_{3}$ nanoparticle anode with a commercial cathode as well as to employ doping or alloy formation to develop an anode that has a lower and more uniform charge/discharge potential. In the first six months, we plan to synthesize larger quantities of HWCVD $\alpha$-phase $\mathrm{MoO}_{3}$ nanoparticles for further evaluation. Research will be conducted to optimize a method for conventional fabrication of $100 \mu \mathrm{m}$ or thicker electrodes. Initially, $80 \%$ active material will be employed with acetylene black and polyvinylidene difluoride. If the particle size of the acetylene black is too large to maintain electrical conductivity between the nanoparticles, we will try ball milling of the acetylene black, use of $\mu \mathrm{m}$-sized particles of graphite, or both to obtain nanoparticle carbon material with an economical method. The thick $\mathrm{MoO}_{3}(\geq 100 \mu \mathrm{m})$ films will then be tested in a coin cell configuration (at University of Colorado by Prof. Se-Hee Lee) as a negative electrode against a commercial $\mathrm{LiCoO}_{2}$ positive electrode.

Additionally, theoretical calculations will be performed to predict doped $\mathrm{MoO}_{3}$ nanoparticles or particles of a specific dimension for negative electrodes that will have a lower discharge potential of about $0.5 \mathrm{~V}$. Later in the year, we will employ HWCVD techniques to produce nanoparticles that are theoretically predicted to have lower discharge potentials as negative electrodes. The electrodes will initially be tested in halfcell configuration to determine a most promising material. In situ Raman studies of all of anode materials will also be performed to understand structural changes during cycling. 


\section{Publications and Presentations}

G.-H. Kim, A. Pesaran, and R. Spotnitz. "A Three-Dimensional Thermal Abuse Model for Lithium-Ion Cells.” Journal of Power Sources, Vol. 170, pp. 476-489, 2007.

G.-H. Kim and A. Pesaran. "Battery Thermal Management Design Modeling." World Electric Vehicle Association (WEVA) Journal, Vol. 1, pp. 126-133, 2007.

T. Markel and A. Simpson, "Cost-Benefit Analysis of Plug-In Hybrid Electric Vehicles," World Electric Vehicle Association (WEVA) Journal, Vol. 1, pp. 053-063, 2007.

G.-H. Kim and A. Pesaran. "Battery Thermal Management Design Modeling." $22^{\text {nd }}$ International Electric Vehicle Symposium. Yokohoma, Japan, October 2006.

A. Simpson and T. Markel, "Cost-Benefit Analysis of Plug-In Hybrid Electric Vehicle Technology," $22^{\text {nd }}$ International Electric Vehicle Symposium, Yokohoma, Japan, October 2006.

A. Pesaran, "Battery Choices and Potential Requirements for Plug-In Hybrids," Presented at the Plug-in Hybrid Electric Truck Workshop Hybrid Truck Users Forum, Los Angeles, California, February 2007.

A. Pesaran and T. Markel, "Battery Requirements and Cost-Benefit Analysis for Plug-In Hybrid Vehicles," Proceedings of the $24^{\text {th }}$ International Battery Seminar and Exhibit, Fort Lauderdale, Florida, March 2007.

T. Markel and A. Pesaran, "PHEV Energy Storage and Drive Cycle Impacts," Presented at Advanced Automotive Battery Conference, Long Beach, California, May 2007.

G.-H. Kim and A. Pesaran. "Analysis of Heat Dissipation in Li-Ion Cells \& Modules for Modeling of Thermal Runaway," The $3^{\text {rd }}$ International Symposium on Large Lithium Ion Battery Technology and Application (LLIBTA/AABC-2007), Long Beach, California, May 2007.

Y.-H. Kim "Lithium Intercalation in Molybdenum Trioxide Nanoparticle" poster at the 24th International Conference on Defects in Semiconductors, Albuquerque, New Mexico, July 18-24, 2007.

A. Pesaran and J. Gonder, "Factors \& Conditions for Widespread Use of Ultracapacitors in Automotive Applications," Proceeding of Advanced Capacitor Summit, San Diego, California, July 2007.

A. C. Dillon, "Characterization of Nanomaterials to Optimize Renewable Energy Applications," presented at the NIST Workshop on Materials Characterization for Nanoscale Reliability, Boulder, Colorado, August, 14-16, 2007. 
G.-H. Kim, K. Smith, A. Pesaran and R. Spotnitz, "Analysis of Thermal Behavior of LiIon Batteries using Thermal Abuse Reaction Model," $212^{\text {th }}$ ECS Meeting, Washington DC, October 2007.

G.-H. Kim and K. Smith, "Multi-Dimensional Electrochemical-Thermal Coupled Model of Large Format Cylindrical Lithium Ion Cells," $212^{\text {th }}$ ECS Meeting, Washington DC, October 2007.

A. Pesaran, T. Markel, H. Tataria, and D. Howell, "Battery Requirements for Plug-In Hybrid Electric Vehicles - Analysis and Rationale," paper to be presented at the $23^{r d}$ Electric Vehicle Symposium, Anaheim, CA, December 2007.

G.-H. Kim, J. Gonder, J. Lustbader and A. Pesaran "Evaluation of HEV Battery Thermal Management with Phase-Change Materials," paper to be presented at the $23^{\text {rd }}$ Electric Vehicle Symposium, Anaheim, CA, December 2007.

A. C. Dillon, A. H. Mahan, R. Deshpande, P. A. Parilla, K. M. Jones and S.-H. Lee "Metal Oxide Nanoparticles for Improved Electrochromic and Lithium-Ion Battery Technologies," Thin Solid Films vol. 216 (in press).

S.-H. Lee, Y-H. Kim, E. Whitney, P. A. Parilla, K. M. Jones, S.B. Zhang and A.C. Dillon, "Anomolous Reversible Lithium-Ion Intercalation in Molybdenum Oxide Nanostructures," Nature Materials (draft submitted).

\section{Milestone Reports}

G.-H. Kim, "Development of Thermal Runaway Propagation Model for Lithium-Ion Battery Modules," Milestone Report, NREL, Golden, Colorado, July 2007.

M. Keyser, J. Lustbader, K. Smith, G.-H. Kim, and J. Gonder, “Thermal Characterization, Evaluation, and Analysis of Lithium-Ion Cells and Modules," Milestone Report, NREL, Golden, Colorado, August 2007.

K. Smith, T. Markel, and G.-H. Kim, "PHEV Battery Design Tradeoffs Analysis," Milestone Report, NREL, Golden, Colorado, September 2007.

S.-H. Lee, Y.-H. Kim, E. Whitney, D. Gillaspie, and A. Dillon, "MoO 3 Nanoparticle Improved Li-Ion Battery Electrodes, " Milestone Report, NREL, Golden, Colorado, September 2007.

A. Frank, K. Zhu, "Update Progress on Oriented Nanotube Arrays for Advanced Lithium-Ion Batteries," Milestone Letter Report, NREL, Golden, Colorado, September 2007. 


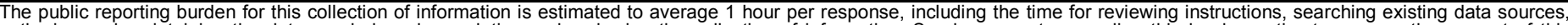

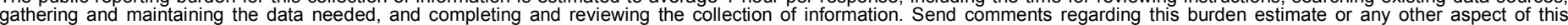

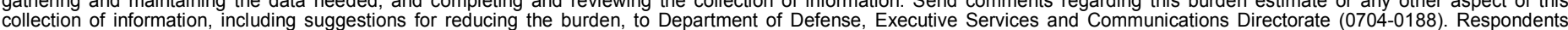

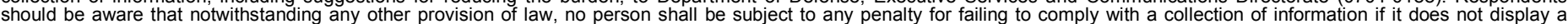

should be aware that notwithstanding

PLEASE DO NOT RETURN YOUR FORM TO THE ABOVE ORGANIZATION.

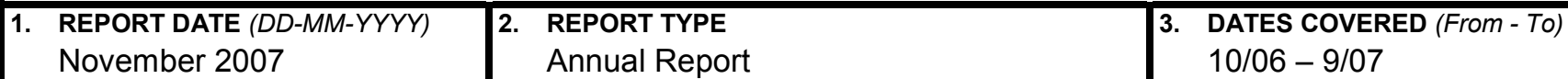

4. TITLE AND SUBTITLE

FY2007 NREL Energy Storage R\&D Progress Report

5a. CONTRACT NUMBER

DE-AC36-99-G010337

5b. GRANT NUMBER

5c. PROGRAM ELEMENT NUMBER

6. AUTHOR(S)

Ahmad Pesaran (Principal Investigator)

5d. PROJECT NUMBER

NREL/TP-540-42716

5e. TASK NUMBER

FC07.6200

Contributors: Matt Keyser, Gi-Heon Kim, Kandler Smith, Jason

Lustbader, Tony Markel, Jeff Gonder, Anne Dillon, Se-Hee Lee,

Yong-Hyun Kim, Dane Gillaspie, Erin Whitney, Art Frank, Kai Zhu,

and Qing Wang

7. PERFORMING ORGANIZATION NAME(S) AND ADDRESS(ES)

National Renewable Energy Laboratory

1617 Cole Blvd.

Golden, CO 80401-3393

9. SPONSORING/MONITORING AGENCY NAME(S) AND ADDRESS(ES)
8. PERFORMING ORGANIZATION REPORT NUMBER

NREL/TP-540-42716
10. SPONSOR/MONITOR'S ACRONYM(S) NREL

11. SPONSORING/MONITORING AGENCY REPORT NUMBER

12. DISTRIBUTION AVAILABILITY STATEMENT

National Technical Information Service

U.S. Department of Commerce

5285 Port Royal Road

Springfield, VA 22161

13. SUPPLEMENTARY NOTES

14. ABSTRACT (Maximum 200 Words)

The National Renewable Energy Laboratory is engaged in research and development activities to support achieving targets and objectives set by the Energy Storage Program at the Office of FreedomCAR and Vehicle Technology in the U.S. Department of Energy. These activities include: 1. supporting the Battery Technology Development Program with battery thermal characterization and modeling and with energy storage system simulations and analysis; 2. supporting the Applied Research Program by developing thermal models to address abuse of Li-lon batteries; and 3. supporting the Focused Long-Term Research Program by investigating improved Li-lon battery electrode materials. This report summarizes the results of NREL energy storage activities in FY07.

15. SUBJECT TERMS

Energy Storage; Batteries; Thermal Characterization; Li-Ion Batteries; Electrodes

\begin{tabular}{|c|c|c|c|c|}
\hline \multicolumn{3}{|c|}{ 16. SECURITY CLASSIFICATION OF: } & \multirow{2}{*}{$\begin{array}{l}\text { 17. LIMITATION } \\
\text { OF ABSTRACT } \\
\text { UL }\end{array}$} & \multirow{2}{*}{$\begin{array}{ll}\text { 18. } & \text { NUMBER } \\
\text { OF PAGES }\end{array}$} \\
\hline $\begin{array}{l}\text { a. REPORT } \\
\text { Unclassified }\end{array}$ & $\begin{array}{l}\text { b. ABSTRACT } \\
\text { Unclassified }\end{array}$ & $\begin{array}{l}\text { c. THIS PAGE } \\
\text { Unclassified }\end{array}$ & & \\
\hline
\end{tabular}

19a. NAME OF RESPONSIBLE PERSON

19b. TELEPHONE NUMBER (Include area code) 